Paper published in:

D. Gallipoli, A.W. Bruno, C. Perlot, J. Mendes (2017).

A geotechnical perspective of raw earth building.

Acta Geotechnica, 12(3): 463-478

http://dx.doi.org/10.1007/s11440-016-0521-1

\title{
A GEOTECHNICAL PERSPECTIVE OF RAW EARTH BUILDING
}

Domenico Gallipoli, Ph.D.

(domenico.gallipoli@univ-pau.fr)

Professor, Université de Pau et des Pays de l'Adour, Pau, France

Agostino Walter Bruno, Dr.Eng.

(agostinowalter.bruno@univ-pau.fr)

PhD student, Université de Pau et des Pays de l'Adour, Pau, France

Céline Perlot, Ph.D.

(celine.bascoules@univ-pau.fr)

Associate Professor, Université de Pau et des Pays de l'Adour, Pau, France

Joao Mendes, Ph.D.

(joaopaulo.duarte@univ-pau.fr)

"Marie Curie" Fellow, Université de Pau et des Pays de l'Adour, Pau, France

Number of words: 7617

Number of tables: 3

Number of figures: 19

Corresponding author: Prof Domenico Gallipoli

Université de Pau et des Pays de l'Adour

Laboratoire SIAME - Bâtiment ISABTP

Allée du Parc Montaury

64600 Anglet

France

e-mail: domenico.gallipoli@univ-pau.fr

\section{ACKNOWLEDGEMENTS}

The financial contributions of the "Conseil régional d'Aquitaine" and the "Agglomération Côte Basque

Adour" through the project MECAD "Matériaux Eco-renforcés pour la Construction et l'Aménagement Durable" (dossier n. 20131101001) is gratefully acknowledged 


\begin{abstract}
Much research has been devoted over the past 30 years to the development of construction materials with low embodied energy that can minimize air conditioning needs and demolition waste, thus lowering the environmental and economic costs of buildings over their entire life. In this respect, raw earth is an attractive material because it is natural and largely available. In its simplest form, this material consists of a compacted mixture of soil and water which is put in place with the least possible transformation. Raw earth construction has been practiced in ancient times but has only recently been rediscovered thanks to modern technology, which has improved fabrication efficiency. If properly manufactured, raw earth exhibits comparable mechanical characteristics and better hygro-thermal properties than concrete or fired bricks. After a brief historical overview, we discuss the advantages of raw earth construction in terms of environmental impact, energy consumption and indoor air quality together with the main obstacles to its wider dissemination. We also review the hydro-thermomechanical behaviour of raw earth in the context of the recent geotechnical literature, by examining the dependency of key parameters such as strength, stiffness and moisture retention on: a) material variables (e.g. particle size and mineralogy), b) manufacturing variables (e.g. density and stabilization method) and c) environmental variables (e.g. pore suction, ambient humidity and temperature).
\end{abstract}

Keywords: raw earth; rammed earth; compressed earth blocks; earthen construction; suction; soil compaction 


\section{INTRODUCTION}

For its $40^{\text {th }}$ anniversary in 2012, the Smithsonian magazine published a catalogue of 40 things to know about the next 40 years. At the top of their list, there was the prediction that "sophisticated buildings will be made of mud".

Observation of nature around us reveals that the above prediction is not so unrealistic as it might seem. Many living creatures inhabit homes that are either dug in soil or made out of soil. These are small organisms such as insects, bacteria, earthworms, snails and fungi or larger animals such as badgers, moles, gophers, snakes and turtles. One of the most interesting examples is provided by African termites, which use mud to build thermo-regulated shelters that buffer the large temperature fluctuations of the savannah and ensure stable indoor hygro-thermal conditions. These earth structures are extremely durable as demonstrated by the finding of well-preserved termite-built mounds that are several hundreds of years old. The above observations have also been corroborated by recent research, which has provided growing support to the use of raw earth for improving the energy efficiency of current construction.

Construction is one the largest industries worldwide (in Europe it accounts for 10-11\% of GDP according to Eurostat [23]) and must embrace the sustainability agenda if global environmental targets are to be met. As an example, the production of cement alone accounts for $5 \%$ of carbon emissions and each ton of cement generates about one ton of carbon dioxide [58]. The use of cement is also expected to grow from 2.5 billion tons in 2006 to 4.4 billion tons by 2050 .

Fig. 1 shows the energy consumption across the building, transport and industry sectors in the United States and Europe as estimated by the OECD [49]. In Fig. 1, only the energy for the operation of dwellings is attributed to the building sector while the energy for the transportation of construction materials is attributed to the transport sector and the energy for the erection and demolition of buildings is attributed to the industry sector. This means that the total energy consumed by all activities associated to construction, operation and demolition of buildings is even greater than that attributed to the building sector in Fig. 1. Szalay [56] arrived to similar conclusions estimating that operation of residential buildings is responsible for about $40 \%$ of all energy consumed. The building 
sector is also the largest consumer of raw minerals and produces about $33 \%$ of all waste in the European Union [20]. Building waste is usually not recycled and is disposed in landfills, which results in loss of land, pollution and social alienation. According to Bossink and Brouwers [4], construction and demolition waste accounts for between $13 \%$ and $30 \%$ of all landfills worldwide, with demolition waste being about twice construction waste [5].

The above considerations have triggered new interest in alternative and more sustainable construction methods which make use of natural, locally-sourced and energy efficient materials. Among these materials, raw earth is one of the most attractive options because it is harmless to humans and can be locally sourced. Earth is also recyclable, inexhaustible and, when properly manufactured, exhibits high strength, excellent hygro-thermal properties and low embodied energy at little cost. Earthen materials have therefore the potential of cutting exploitation of natural resources not only during construction but also during operation and at the end-of-life of buildings, thus reducing air conditioning and unrecyclable demolition waste.

Unlike the "cooked earth" of conventional bricks, raw earth is unfired and subjected to the least possible transformation before being put in place. Sometimes, fibres or chemical binders such as lime or cement are added to increase inter-granular bonding and enhance strength. When lime or cement are added (typically in the proportion of $6 \%$ by weight), the material is referred as "stabilized earth" to mark a difference with respect to "unstabilized earth", which contains no binders and whose strength originates from the inter-particle capillary "pull” exerted by water.

This means that unstabilized earth structures can be regarded as soil fills in the shape of buildings and, likewise geotechnical fills, their properties depend on the manufacturing process. The moisture content of raw earth buildings is highest after construction but rapidly reduces as water evaporates and fluctuates, in the long term, around an average value. Given these similarities with soil fills, the design of raw earth buildings could benefit from current knowledge in unsaturated soil mechanics. In this paper, we highlight the opportunities for application of geotechnical knowledge to raw earth construction and review the most important properties of this material in the context of recent research. 


\section{HISTORICAL OVERVIEW}

Historical earth structures, from rural habitats to impressive military citadels, can be found all over the world, e.g. in France, Spain, Portugal, the Maghreb region (Morocco, Algeria), Central and South America (Mexico, Peru, Brazil) and China.

Archaeological remains indicate that, between 1500 and 300 BC, the Phoenicians had developed a building technique based on raw earth in the cities of Tyr, Ugarit and Sidon. This technique was subsequently exported by the Carthaginians to the entire Mediterranean region.

Other ancient examples of rammed earth construction include sections of the Great Wall of China erected over 2000 years ago and the Alhambra Palace in Spain built in the 10th century. Similar techniques were also developed by some pre-Columbian civilizations.

During the late eighteenth century and throughout the nineteenth century, earthen construction experienced a strong revival due to the initiative of the Lyonnais architect and professor of rural architecture François Cointeraux (1740-1830). Cointeraux was an ardent propagator of this construction technique and his writings contributed to the dissemination of earthen buildings throughout Europe (e.g. in France, Germany, Italy, Switzerland and Denmark) and in the United States and Australia. One of the most famous definitions of rammed earth ("pisé de terre" in French) appears in his publication "Ecole d'Architecture Rurale" (1790-1791) [14]:

«the "pise"” is a process by which houses are built from earth without the support of wood and without mixing straw or other filling. It consists in compacting, layer by layer, between two wooden planks, separated by the thickness of an ordinary wall, a given amount of earth prepared for this purpose. Compacted in this way, the earth binds, takes consistency and forms a homogeneous mixture that can be erected to heights suitable for dwellings». (translated from French)

In the Rhône-Alpes region of France, a large number of earthen buildings dating back one or two hundred years ago are still inhabited and exhibit excellent performance in terms of structural stability, durability and environmental comfort. In France, the revival of earthen construction lasted until the 
beginning of the past century and affected a varied typology of buildings such as farms, barns, mansions, castles, churches, factories, mills, housing estates, town halls and schools.

During the same period, earthen construction was also widely practiced in Gemany where the six storey "Haus Rath", built in 1828 by the industrial Jacob Wimpfin in Weilburg an der Lahn, is probably the tallest earth building to date. Between 1920 and 1950, a vast programme of promotion of earthen construction was launched by the political authorities of the time especially in the regions of Prussia and Saxony, which resulted in the realization of nearly twenty thousand dwellings.

After the Second World War, the large reconstruction effort required fast building techniques with little consideration of environmental impact. Materials such as concrete and steel rapidly turned into the preferred choice of architects and engineers. Raw earth became increasingly obsolete and, by the end of the 1950s, was virtually abandoned in the developed world. Yet, about 50\% of current world population lives in earth dwellings that are mainly legacy structures from the past or new buildings in poor countries [26].

Earthen construction has always been regarded as an "art" transmitted from generation to generation. This art was practiced by craftsmen with good empirical knowledge of the hydro-thermo-mechanical properties of earthen materials and a sound experience of the construction process. The loss of these skills is one of the main obstacles to the utilization of raw earth in current construction practice.

\section{ANCIENT RAW EARTH CONSTRUCTION}

The following ancient techniques of earthen construction have been developed centuries ago but are still employed, sometimes with little changes.

- Cob. This technique consists in the construction of massive load bearing walls made of soil, water and natural fibres (e.g. straw, reed or heath). The soil/fibre mixture is manufactured in a very wet state into clods that are $50 \mathrm{~cm}$ to $120 \mathrm{~cm}$ large. The dimension of the clods depends on plasticity and particle size of the soil, but also on the experience of the builder. Clods are stacked in consecutive lifts without formworks and trimmed to provide a smooth surface. Walls are usually 50-60 cm thick, for single-floor buildings, and 70-80 cm tick, for two-floor 
buildings. Because of the high water content and plasticity of the clods at the time of emplacement, each lift must dry for about four weeks before the subsequent one is placed on top. Cob building is therefore time consuming but offers the flexibility of producing walls of variable shapes (e.g. non-rectilinear walls).

- Adobe. Similar to cob construction, this technique uses a very wet mixture of soil, water and natural fibres. The mixture, which has the consistency of a thick mud, is poured into parallelepiped moulds with dimensions of conventional bricks and dried to the sun for several days. After this, the blocks are extruded and used to build masonry structures likewise ordinary bricks.

- Mud blocks. This technique uses a plastic mixture of soil, water and natural fibres and is very similar to adobe (indeed the terms adobe and mud blocks are often used interchangeably). In general, mud blocks are cut to size rather than being moulded, like adobe, before being dried to the sun for two weeks. This very ancient technique dates back to the Neolithic and it was widely practiced in Mesopotamia and Egypt [36].

- Wattle and daub ("Torchis" in French). This is a very old technique for the construction of non-load bearing walls, either partition walls or external walls, with thicknesses between $8 \mathrm{~cm}$ and $20 \mathrm{~cm}$. The technique consists in filling a lattice of inter-woven wooden strips with a wet mixture of soil and vegetal fibres like straw or hemp. A heavyweight and lightweight version of wattle and daub can be distinguished. In the heavyweight version, the soil mix includes only a small amount of vegetal fibres. This increases thermal capacity, which in turn makes the material best suited for internal walls. In the lightweight version, a significant portion of the soil is replaced by vegetal fibres, which improves thermal insulation and makes the material best suited for external walls.

- Rammed earth ("Pisé" in French). Rammed earth structures are traditionally built by manual compaction of moist earth in consecutive layers inside a formwork of parallel flat shutters. The shutters, which have typical lengths of 700-1000 mm and heights of 600-900 mm, are held at a distance equal to the wall thickness by props and rope ties. Between $10 \mathrm{~cm}$ and 25 $\mathrm{cm}$ of moist loose earth is poured inside the formwork and compacted by about $50 \%$. Earth is 
tamped with a ramming pole, layer after layer, until attaining the top of the formwork. At this point, the shutters are dismantled and moved either horizontally, to build the next section of the current lift, or vertically, to start a new lift.

\section{EARTH AS A SUSTAINABLE MATERIAL FOR MODERN CONSTRUCTION}

The excellent environmental credentials of raw earth have led to a renaissance of this construction technique in recent years. The main difference between modern and ancient earth construction relates to the building process. For example, rammed earth structures are nowadays fabricated with the help of heavy compaction machinery inside large metallic formworks placed on rollers or slides to facilitate displacement and speed up construction. Other earth building techniques have also been developed with the objective of optimizing quality control, increasing construction efficiency and reducing labour and material costs. These techniques include: a) prefabricated rammed earth panels which are produced either on-site or off-site, b) compacted earth blocks which are fabricated by portable presses with capacities up to $15 \mathrm{MPa}$ and c) casted earth which is a variation of concrete where the cement binder is replaced by clay.

The renaissance of raw earth construction in recent times has been prompted by the following advantages, which have been known for years but have started to be quantified only recently:

- Reduction of embodied energy. Extraction, transportation and manufacture of earthen materials only require $1 \%$ of the energy necessary to produce cement-based materials [18]. Similarly, the manufacture of compressed earth blocks requires, at most, one third of the energy to fabricate conventional fired bricks, namely $440 \mathrm{kWh} / \mathrm{m}^{3}$ compared to $1300 \mathrm{kWh} / \mathrm{m}^{3}$ [41].

- Reduction of operational energy (hygro-regulator effect). The nanoporous fabric of earthen materials results in very good hygroscopic properties including the ability of adsorbing vapour from humid environments. Moisture is stored in the pore space and is released back when the atmosphere becomes drier, with mass fluctuations up to $3 \%$. Earth walls can therefore passively regulate hygrometric conditions inside buildings. 
- Reduction of operational energy (thermal-regulator effect). Raw earth exhibits a higher specific heat (of the order of $10^{3} \mathrm{~kJ} / \mathrm{m}^{3} \mathrm{~K}$ ) than standard insulating materials used in construction (of the order of $10^{1}-10^{2} \mathrm{~kJ} / \mathrm{m}^{3} \mathrm{~K}$ ) [30]. Unfortunately, it also has a higher thermal conductivity (of the order of $10^{-1} \mathrm{~W} / \mathrm{mK}$ ) than standard insulating materials (of the order of $10^{-}$ ${ }^{2} \mathrm{~W} / \mathrm{mK}$ ). The above properties, however, do not take into account the additional thermalregulator effect associated to the capillary condensation/evaporation of water inside the earth nanopores (see point above). Evaporation is an endothermic process, which takes latent heat from the atmosphere during hot times while condensation is an exothermic process which releases latent heat during cool times. This liquid/gas phase change inside earth walls results in heat withdrawal during the day and heat release during the night with a phase shift of 10-12 hours, thus helping to stabilize indoor temperature [30].

- Recycling or disposal of demolition waste. Demolition of unstabilized earth structures produces "clean" waste consisting of natural soil which is easily recycled or disposed. This is not the case for stabilized earth structures where the use of chemical binders, such as lime or cement, complicates recycling.

- Acoustic insulation. Earth walls present excellent acoustic properties due to their high dry density and thickness, usually above $2000 \mathrm{~kg} / \mathrm{m}^{3}$ and $0.25 \mathrm{~m}$, respectively. According to British Standard 8233 [8], the sound reduction index $R(\mathrm{~dB})$ of an ordinary masonry wall depends on its dry density, $\rho\left(\mathrm{kg} / \mathrm{m}^{3}\right)$ and thickness, $t(\mathrm{~m})$ as:

$$
R=21.65 \log (\rho t)-2.3
$$

Equation 1 predicts that an earthen wall with a thickness of $0.30 \mathrm{~m}$ and a dry density of 2100 $\mathrm{kg} / \mathrm{m}^{3}$ has a relatively high sound reduction index of $58.3 \mathrm{~dB}$. For comparison, the British Building Regulations [6] specify that the sound reduction index for internal walls and floors within rooms for residential purposes should be at least $40 \mathrm{~dB}$.

\section{LIMITATIONS OF RAW EARTH CONSTRUCTION}

In spite of recent technological progress, the adoption of raw earth by mainstream construction practice is still hindered by a number of obstacles, some of which are summarized below: 
- Inadequacy of local soil. Earthen construction employs soil mixes with variable proportions of gravel, sand, silt and clay. The exact influence of soil grading on the strength and durability of raw earth remains unclear [34] but most studies agree that an optimum mix for unstabilized earth construction should include between $20 \%$ and $40 \%$ of clay/silt and between $80 \%$ and $60 \%$ of sand/gravel. Fig. 2 shows the particle size distribution of a typical earthen material. In this case, the clay fraction is relatively small (around 10\%) but plays the two important roles of binding coarser grains through capillarity and enhancing the moisture buffer properties of the material. If the recommended proportions of clay, silt, sand and gravel are not available locally, they must be sourced elsewhere and transported to site. Local but less suitable soils can still be used but they must be first stabilized by chemical binders (e.g. cement) to compensate for the original substandard properties. Regardless of whether good soils are imported from further away or local but less suitable soils are stabilized, the energy and carbon footprint of the final product will inevitably increase.

- Poor quality control. Two levels of quality control can be identified with reference to earthen construction, a "precautionary" level and a "confirmatory" level. The precautionary level consists in monitoring the selection, mixing and storage of soil constituents prior to compaction. The confirmatory level consists in ensuring that the final density, strength and durability of the built product are compliant with design requirements. The former level of control can be performed on site with relative ease, while the latter one is more difficult to accomplish as material characteristics remain highly dependent on workmanship [15].

- Long construction times. This limitation mainly applies to rammed earth buildings, which are probably the slowest to build. Soil ramming can be more or less fast depending on whether is performed manually or with electrical/diesel-powered machinery. However, the continuous setting-up, aligning and stripping of formworks take considerable time and account for up to $60 \%$ of site operations. Building time increases considerably for projects requiring significant dismantling and reassembly of formworks with escalating costs that make realizations unviable [43]. 
- Empiricism of design methods. Several countries (e.g. Australia, New Zealand, USA, Zimbabwe, Germany and Spain) have published national standards for earthen construction which are based on empiricism rather than engineering science. These documents state that raw earth must "cure" for weeks before gaining full strength, though the physical nature of this curing process is not explicitly recognized. Unlike concrete, curing of raw earth involves evaporation of pore water, which increases capillary tension and results in stronger intergranular bonding [32]. This advantageous effect of capillary tension, if properly quantified, could cut safety margins, thus reducing construction costs and environmental impact.

- Sensitivity to moisture ingress. The wicking action of small earth pores causes the rapid absorption of any free water with which the material comes into contact. Experiments have shown that, during the initial phase of exposure of raw earth to free water, the moisture content increases linearly with the square root of time, a phenomenon named the "wick effect" $[42,57]$. Moisture ingress reduces material strength and, depending on soil mineralogy, may cause swelling of the clay component, which in turn produces structural damage. Moisture ingress can however be limited by controlling pore volume, pore size and degree of saturation as shown by Hall and Djerbib [27].

- Durability. In dry climates raw earth is very durable as demonstrated by structures dating back hundreds, or even thousands, of years. In wet climates, however, rainfall causes surface erosion especially in unstabilized earth structures. Bui et al. [11] measured between $5 \mathrm{~mm}$ and $10 \mathrm{~mm}$ of erosion from the surface of a $400 \mathrm{~mm}$ thick unstabilized earth wall exposed to a wet continental climate during twenty years. Another unstabilized earth wall, built on the campus of the Massachusetts Institute of Technology in 2005, has shown a surface erosion of about 5$7 \mathrm{~mm}$ during nine years of exposition to the temperate climate of the northeastern coast of United States [16]. Extrapolation of these results indicates that between $25 \mathrm{~mm}$ and $80 \mathrm{~mm}$ of surface erosion can be expected over 100 years, which is not acceptable for most structures. Freeze-thaw cycles can also induce spalling, especially if these cycles occur soon after construction when the material is still relatively wet and hence particularly vulnerable to sub- 
zero temperatures. Tests by Guettala et al. [24] have observed a loss of $2 \%$ of earth mass after 12 freeze-thaw cycles between $21{ }^{\circ} \mathrm{C}$ and $-23{ }^{\circ} \mathrm{C}$.

- Reliance on chemical stabilizers. Traditional earth stabilizers are cement, lime and bitumen, which are added to the soil in proportion between $5 \%$ and $15 \%$ by weight. These binders increase strength, improve durability, reduce shrinkage/swelling and provide waterproofing. However, besides these benefits, they bring at least three disadvantages. Firstly, they increase cost as stabilizers can account for more than half of the overall material price. Secondly, they considerably increase carbon footprint. Lax [40] has shown that addition of 9\% of Portland cement increases the embodied carbon of earthen materials to similar levels as fired bricks or concrete. Thirdly, they complicate the recycling of demolition waste because stabilized earth is no longer a natural material but rather a "weak concrete" made of aggregates linked by a chemical binding matrix [13].

- Uncertainties about energy efficiency. Past studies have already shown that raw earth exhibits lower levels of embodied energy compared, for example, to concrete or steel [39]. A similar quantification of operational energy is, however, not available due to the currently poor understanding of the hygro-thermal inertia of earth structures. At the same time, it is common knowledge that fluctuations of temperature and humidity inside earth buildings are relatively small and that air conditioning needs are significantly reduced compared to other structures. Other uncertainties also apply to the end-of-life energy, i.e. the energy spent during demolition and disposal of earth buildings. The above gaps of knowledge have impeded a full appreciation of the energy performance, and hence of the low environmental impact, of these structures over their entire life, i.e. during construction, operation and end-of-life.

\section{HYDRO-THERMO-MECHANICAL PROPERTIES OF RAW EARTH}

Stiffness, strength and moisture retention are key material properties that govern the behaviour of raw earth during service life and at ultimate state. The dependency of these properties on pore suction has been extensively studied by geotechnical engineers for different types of soils. For example, geotechnical engineers already know that soils become stiffer, stronger and more impermeable as 
suction increases and that, depending on their density, soils can either shrink or swell as pore suction is reduced. These aspects of material behaviour are implemented in several geotechnical models, which have however found little application to raw earth construction. This is partly due to differences in material characteristics as the soils studied by geotechnical engineers are prevalently fine with relatively low densities whereas raw earth is relatively dense with a dominant sandy-gravelly fraction. This is illustrated in Fig. 3, which shows the recommended lower and upper limits of the different fractions of unstabilized raw earth according to various authors.

Another reason for the limited application of geotechnical models to the analysis of raw earth buildings is that these buildings are typically designed as assemblies of discrete blocks, similar to masonry, rather than as porous continua likewise geotechnical fills. This approach has, however, been questioned by Langenbach [38] after observing that the majority of damages to earth structures during the 2003 earthquake in Bam (Iran) was caused by loss of cohesion which is better explained by porous continuum theories than masonry models.

In the following, we review some recent studies about the hydro-thermo-mechanical behaviour of raw earth materials. We focus on the dependency of the stiffness, strength and moisture retention properties on: a) material variables such as particles size and clay mineralogy, b) manufacturing variables such as density and stabilization and c) environmental variables such as pore suction, ambient humidity and temperature.

\section{Effect of particles size on stiffness, strength and moisture retention}

Wu et al. [59] have demonstrated the significance of soil grading for the mechanical behaviour of raw earth by analysing four earthen materials with a coarse sandy-gravelly fraction between $60 \%$ and $45 \%$ and a fine clayey-silty fraction between $40 \%$ to $55 \%$. All four materials were lightly compacted at a water content of $19.5 \%$ into parallelepiped wood moulds with dimensions of 200x90x50 mm and, after drying, were subjected to unconfined compression. Results show that strength and stiffness grow as the clayey-silty fraction increases from $40 \%$ to $50 \%$ but start to reduce as the clayey-silty fraction increases further from $50 \%$ to $55 \%$. 
With reference to the effect of particles grading on the retention characteristics of raw earth, two comprehensive studies were undertaken by Jaquin et al. [31] and Beckett and Augarde [3].

Jaquin et al. [31] performed filter paper tests on one coarse and one fine earth material referred to as mix A and B, respectively. These two materials were obtained by modification of a base earth (Fig. 2) via the addition of an extra $10 \%$ of sand (mix A) and an extra $10 \%$ of clay/silt (mix B). Both mixes were statically compacted at a water content of $10 \%$ to a dry density of $2050 \mathrm{~kg} / \mathrm{m}^{3}$.

Similarly, Beckett and Augarde [3] tested a coarse earth consisting of 70\% sand, 10\% gravel and 20\% clay (mix 7-1-2) and a fine earth consisting of 50\% sand, $10 \%$ gravel and $40 \%$ clay (mix 5-1-4). These two mixes contained the minimum and maximum amounts of clay recommended by Houben and Guillaud [29] while the gravel content was the minimum recommended. The materials were statically compacted in layers, at a water content of $12 \%$, to a dry density between $1918 \mathrm{~kg} / \mathrm{m}^{3}$ and $1947 \mathrm{~kg} / \mathrm{m}^{3}$, which is about equal to the light Proctor optimum.

The retention curves measured in both studies from Jaquin et al. [31] and Beckett and Augarde [3] are shown in Fig. 4. Despite the fine and coarse samples of each study exhibit similar values of the overall pore volume, the former samples retain more water than the latter ones. This larger hydrophilicity is explained by a dominance of small voids, which confirms that both overall pore volume and pore size distribution have an influence on the moisture buffering characteristics of the material.

\section{Effect of clay mineralogy on moisture retention}

The hydro-mechanical behaviour of raw earth is significantly influenced by the type of clay fraction. Clays with different structures and chemical properties induce different responses to mechanical or environmental actions. "Two-layer" clays, such as kaolinite, are characterised by a relatively low specific surface (about $10 \mathrm{~m}^{2} / \mathrm{g}$ ) which results in limited swelling/shrinkage upon wetting/drying but also in a weak bonding of the coarse fraction. Conversely, "three-layer" clays are characterised by a large specific surface (up to $1000 \mathrm{~m}^{2} / \mathrm{g}$ ) and are therefore strong binders of the coarse fraction. The higher bonding capacity of three-layer clays compared to two-layer clay is due to their ability of 
generating higher suctions at the same moisture content. Three-layer clays are also divided into two categories, i.e. non-swelling clays (Micas and Illite) and swelling clays (Smectite).

The type of clay employed during construction is often dictated by local availability, yet it is important to assess properties for optimizing application. For example, two-layer clays are best suited for surface coatings because of their reduced cracking due to the limited swelling/shrinkage. Conversely, for structural applications such as load-bearing walls, three-layer non-swelling clays are most appropriate because of their powerful binding properties. If locally available clays are not suitable for the envisaged application, natural fibres such as straw, flax, hemp or cellulose can be added to enhance inter-granular bonding and/or reduce swelling/shrinkage while limiting environmental impact [52].

\section{Effect of density on stiffness and strength}

Several authors have investigated the relationship between raw earth density and mechanical properties [37, 47, 50]. Morel et al. [47] examined the strength of blocks made of both unstabilized and stabilized earth. Fig. 5 shows the results from this study and indicates that strength increases with increasing dry density regardless of whether the fine fraction is a non-swelling "two-layer" clay, such as kaolin, or a swelling "three-layer" clay, such as bentonite.

A similar study by Kouakou and Morel [37] compared the mechanical behaviour of traditional adobe blocks and pressed adobe blocks (PAB) fabricated from an earth mix of 44,5\% sand, 30,0\% silt and $25,5 \%$ clay, which results in a liquid limit of $38 \%$ and a plasticity index of $18 \%$. Traditional adobe blocks were manufactured by pouring the mix at a high water content inside wooden moulds with dimensions of $310 \times 152 \times 73 \mathrm{~mm}$ and by subsequently drying the demoulded blocks to the sun. Instead, the pressed adobe blocks were compressed to $2 \mathrm{MPa}$ at a much lower water content. Interestingly, Fig. 6 shows that both materials appear to follow the same non-linear increase of compressive strength with dry density.

Based on this evidence, Bruno et al. [9] attempted to improve the strength and stiffness of unstabilized compressed earth by increasing dry density though the application of very large compaction pressures. The soil used by Bruno et al. [9], whose characteristics are summarized in Table 1, comply with the 
prescriptions of Jiménez Delgado [33] for raw earth construction. Samples were statically compacted in cylindrical moulds (diameter of $50 \mathrm{~mm}$ and height of $100 \mathrm{~mm}$ ) by applying different pressures of 25 $\mathrm{MPa}, 50 \mathrm{MPa}$ and $100 \mathrm{MPa}$ during a period of time long enough to dissipate any excess pore pressure. As a term of comparison, earth blocks are usually compacted at much lower pressures between $2 \mathrm{MPa}$ and $15 \mathrm{MPa}$.

The three compaction curves by Bruno et al. [9] are shown in Fig. 7 together with the standard Proctor curve as a reference. For the highest compaction pressure of $100 \mathrm{MPa}$, the maximum dry density was about $2270 \mathrm{~kg} / \mathrm{m}^{3}$, corresponding to an optimum water content of $5 \%$. To the authors' knowledge, this is the largest dry density ever registered in the literature for an unstabilized earthen material. As compaction increases, the curves of Fig. 7 shift toward the theoretical "no porosity" point where the dry density becomes equal to the density of the solid particles. Density increases less than linearly with compaction pressure, i.e. the increase from $50 \mathrm{MPa}$ to $100 \mathrm{MPa}$ is less than the increase from 25 $\mathrm{MPa}$ to $50 \mathrm{MPa}$, which means that an unfeasibly high pressure would be necessary to attain the theoretical no porosity point.

Compacted samples were subsequently equalized in a climatic chamber at a temperature of $25^{\circ} \mathrm{C}$ and a relative humidity of $60 \%$, which resembles typical service conditions. During equalization, all samples dried to the same water content of about $3.5 \%$ but exhibited shrinkages of different magnitudes depending on whether they were wetter or drier (Fig. 8). These differences in shrinkage tended to reduce as the compaction pressure increased.

Inspection of Fig. 8 also indicates that all samples compacted to $100 \mathrm{MPa}$ present an almost identical dry density after equalization of about $2280 \mathrm{~kg} / \mathrm{m}^{3}$. Therefore, the application of very high compaction pressures during manufacture of earth blocks can results in virtually identical dry densities after ambient equalization regardless of the compaction water content. This suggests that the "hypercompaction" procedure proposed by Bruno et al. [9] can also facilitate quality control during fabrication.

Fig. 9 and Fig. 10 present the variation of stiffness and strength with dry density measured by Bruno et al. [9]. Similar to Kouakou and Morel [37], both Young's modulus and compressive strength increase 
more than linearly with increasing dry density, which indicates that any further marginal reduction of porosity can produce a significant improvement of mechanical properties.

Table 2 shows that the hypercompacted unstabilzed earth manufactured by Bruno et al. [9] exhibits a strength that compares well with that of traditional construction materials such as stabilized earth or fired bricks. In Table 2, the maximum strength measured by Guettala and Guenfoud [25] for stabilized earth, i.e. $12.9 \mathrm{MPa}$, was obtained by adding a relatively high fraction of cement equal to $10 \%$, which virtually erases all environmental benefits of the earthen material.

\section{Effect of stabilization on moisture buffering}

Raw earth materials are strong hygroscopic buffers and can therefore smooth fluctuations of indoor humidity through adsorption and desorption of atmospheric moisture. The hygroscopic behaviour is often described by means of a single parameter, i.e. the Moisture Buffer Value (MBV), which is experimentally determined by cyclically exposing a sample to two distinct levels of relative humidity for fixed periods of time. These cycles, which simulate the daily changes of indoor climate, are continued until a steady state is attained, i.e. until the moisture gained by the material at the high humidity level becomes equal to the moisture lost at the low humidity level. The MBV is then calculated by dividing the moisture gain or loss (in $\mathrm{g}$ ) by the exposed surface (in $\mathrm{m}^{2}$ ) and the imposed relative humidity change (in $\% \mathrm{RH})$.

A number of procedures have been proposed to measure the MBV, which differ for the magnitude and duration of the two humidity stages but also for the constant temperature at which the entire test is performed. These experimental factors can significantly affect results, which means that a meaningful comparison of MBVs is only possible if the same testing procedure is followed.

McGregor et al. [44] determined the MBVs of both unstabilized and stabilized compressed earth samples. The samples were statically compacted by using a press with a capacity of $50 \mathrm{kN}$ inside a standard Proctor mould. Stabilisation was achieved by adding either a conventional binder, such as cement or lime, or a geoploymerization catalyst, such as sodium hydroxide $(\mathrm{NaOH})$. Two samples were stabilized with cement and two samples with lime, each pair containing respectively $4 \%$ and $8 \%$ 
of stabilizer per dry mass. A fifth sample was instead stabilized with $3 \%$ of dissolved sodium hydroxide per dry mass. This amount of sodium hydroxide was chosen according to the indications given by Davidovits [17] for geopolymer composition.

The MBVs were measured by subjecting the samples to relative humidity cycles between $50 \%$ and $85 \%$ for times of $8 \mathrm{~h}$ and $16 \mathrm{~h}$, respectively. Results are shown in Fig. 11 which indicates that unstabilized earth exhibits the highest MBV among all five materials. Interestingly, the addition of any type of stabilizer reduces the MBV, though the effect is most significant when sodium hydroxide is used. In the case of cement and lime, the reduction of moisture buffering increases as the stabilizer percentage grows. Also, cement and lime appear to have the same effect on moisture buffering as samples prepared with identical percentages of these two binders exhibit very similar MBVs.

McGregor et al. [45] compared the moisture buffering behaviour of traditional, e.g. lime or gypsum, plasters with that of alternative clay plasters when subjected to humidity cycles between $50 \%$ and $80 \%$ for $12 \mathrm{~h}$. Fig. 12 shows the results from a steady state cycle, which indicates that clay plasters exhibit a moisture uptake between 30 and $70 \mathrm{~g} / \mathrm{m}^{2}$, well above the value of traditional lime or gypsum plasters. McGregor et al. [45] also observed that clay plasters exhibit significantly lower moisture uptake that unstabilized earth blocks. Such observation is explained by the fact that earth blocks tend to include a small percentage of swelling minerals while clay plasters do not (otherwise they would crack because of their limited thickness).

\section{Effect of pore suction on stiffness and strength}

The influence of pore suction and water content on the strength and stiffness of raw earth has been studied by Jaquin et al. [32]. These authors studied a mix of coarse aggregate, alluvial sand and powdered clay/silt in proportion of 0.60: 0.25: 0.15 (Fig. 2). Samples were manufactured at a water content of $12 \%$ by vibrating hammer compaction [7], which better resembles the process of rammed earth construction. This produced a dry density between $2017 \mathrm{~kg} / \mathrm{m}^{3}$ and $2061 \mathrm{~kg} / \mathrm{m}^{3}$. The optimum water content was later measured between $8 \%$ and $10 \%$, which means that the tested material was slightly wet of optimum. After compaction, the samples were dried to different water contents and subjected to unconfined axial compression while suction was measured by a high capacity tensiometer 
mounted on the sample side. Inspection of Fig. 13 indicates that strength and stiffness increase with decreasing water content and that, during axial compression, pore suction increases for specimens at high water content but decreases for specimens at low water content. The material also becomes progressively more fragile as it becomes drier.

Another recent study by Bui et al. [10] confirmed the above results and showed that both strength and stiffness increase as suction grows. Table 3 summarizes the grain size distribution of the three materials tested by Bui et al. [10]. Materials A and C are both unstabilized earths while material B is stabilized with $2 \%$ in weight of natural hydraulic lime (NHL). Earthen samples were dynamically compacted at a water content of $11 \%$ in six layers according to the standard Proctor method [1]. This resulted in a dry density of $1920 \mathrm{~kg} / \mathrm{m}^{3}$, which is within the typical range for rammed earth [12]. After compaction, the samples were dried at the atmosphere to different moisture contents. Suction was then measured by filter paper before performing unconfined compression tests. The measured values of stiffness and strength are plotted against the corresponding values of suction in Fig. 14 and Fig. 15, respectively. Fig. 15 also includes the strength measured in the previous study by Jaquin et al. [32] on a material with a slightly higher dry density. Inspection of Fig. 14 and Fig. 15 indicates that stiffness and strength increase linearly with the logarithm of suction according to a relationship that is similar for different materials.

\section{Effect of ambient humidity and temperature on stiffness and strength}

The indoor and outdoor sides of a building envelope are usually exposed to very different ambient conditions. This can produce large gradients of temperature, humidity and pore suction across the thickness of perimeter walls. The impact of these gradients on structural performance has however been the object of very limited investigation to date.

Dierks and Ziegert [19] showed that the unconfined compressive strength of raw earth reduces as ambient humidity increases and, hence, as water condenses inside the pores of the material thus producing a decrease of suction. Fig. 16 indicates that, for the material tested by Dierks and Ziegert [19], strength reduces from about 5,7 MPa at an ambient humidity of 5\% (suction of $405 \mathrm{MPa}$ ) to about 2,3 $\mathrm{MPa}$ at an ambient humidity of $95 \%$ (suction of $7 \mathrm{MPa}$ ). Note that we have calculated the 
above suction values from the humidity measurements of Dierks and Ziegert [19] by using Kelvin equation and assuming a constant temperature of $25^{\circ} \mathrm{C}$.

Similar results were obtained by Beckett and Augarde [3], who investigated the unconfined compressive strength of the previously described earth mixes 5-1-4 and 7-1-2 at different temperatures (between $15{ }^{\circ} \mathrm{C}$ and $40{ }^{\circ} \mathrm{C}$ ) and relative humidities (between $30 \%$ and 90\%). Strength was generally higher for the earth mix with lower clay content and increased with decreasing humidity and increasing temperature. By using Kelvin equation, we have converted the pairs of temperature and humidity tested by Beckett and Augarde [3] into a single suction value. The compressive strength has then been re-plotted against suction in Fig. 17 where all data are interpolated by a single linear relationship despite some differences between the two earth mixes. Fig. 17 also shows the results by Bui et al. [10] and Jaquin et al. [32] already presented in Fig. 15. The samples tested by Beckett and Augarde [3] exhibit lower values of strength compared to Bui et al. [10] and Jaquin et al. [32]. Interestingly, however, the samples tested by Beckett and Augarde [3] and Bui et al. [10] have very similar dry densities and particle size distributions, which means that any difference of strength must be rather attributed to soil mineralogy.

The above results indicate that, during design of earth buildings, it is important to take into account any change of environmental conditions that can potentially occur over the life cycle of the structure.

\section{STABILIZATION METHODS}

Stabilization of raw earth by means of chemical binders increases the costs of buildings, boosts the carbon footprint of construction and makes demolition waste no longer recyclable or easily disposable. Chemical stabilisation also considerably increases the levels of operational energy as it significantly lessens the moisture buffering characteristics of raw earth and therefore reduces the possibility of passively regulating indoor humidity and temperature [44].

At the same time, stabilization is often inevitable to improve the durability of raw earth especially in wet climates. Traditional hydraulic binders, such as cement and lime, have been widely used with reasonably good performances. These binders do not prevent, however, infiltration of liquid water, 
which may eventually lead to mould growth and efflorescence. Some authors have therefore explored the use of alternative admixtures that can repel liquid water at the surface while allowing vapour transfer through the material in order to retain the advantageous hygroscopic properties.

Among these admixtures, silicone-based products are probably the most effective. For example, Kebao and Kagi [35] observed that the addition of $0.05 \%$ of a silicone-based water-repellent admixture to a cement stabilized rammed earth reduced water absorption by $80 \%$ in comparison with the untreated material. Silicone-based water-repellent admixtures contain silane and siloxane that react with the soil substrate by creating a layer of hydrophobic nanomolecular polysiloxane inside capillary pores. This polysiloxane layer is chemically bound to the soil substrate, which assures the long term durability of the treatment. An additional advantage is that silicone-based admixtures do not modify the appearance of the material.

Alternatively, surface treatments can be applied to raw earth walls to reduce water infiltration and hence to improve material durability. Some authors have suggested the application of acrylic or latex emulsions to form a protective film on the material surface which impedes penetration of liquid water. The existence of a surface cover presents, however, at least two disadvantages: a) a drastic reduction of vapour permeability and of the associated moisture buffering capabilities and b) a permanent modification of the material appearance. In addition, surface films can be damaged by UV radiation or weathering, which undermines the long term durability of the treatment.

To overcome these limitations, Kebao and Kagi [35] employed the previously described silicon-based admixtures as surface treatments. This significantly reduced water adsorption (Fig. 18) without however impeding vapour transmission as measured by air blowing (Fig. 19). The reason of this behaviour is that silicon-based sealers present smaller molecular sizes than acrylic or latex emulsions and can easily penetrate the earthen material thus forming a thicker water-repellent layer that covers the inner pore surface. Because of this, they are also less sensitive to UV radiation or weathering and can achieve longer life spans.

Alkaline activation is another stabilization method that has been used to reduce water infiltration and to improve the durability of raw earth. This method induces a transformation of the native clay 
minerals into non-swelling binders by means of alkaline solutions acting as catalyzers. The most common alkaline activators are $\mathrm{Ca}(\mathrm{OH})_{2}, \mathrm{NaOH}$ and $\mathrm{KOH}$.

Slaty et al. [54] investigated the durability of an earth mix consisting of $42.0 \%$ kaolinitic clay, $42.0 \%$ silica sand, 9.3\% water and activated with $6.7 \%$ of $\mathrm{NaOH}$. Unlike other studies, the kaolinitic clay ( $74 \% \mathrm{SiO}_{2}, 26 \% \mathrm{Al}_{2} \mathrm{O}_{3}$ ) was not previously calcinated to be converted into metakaolin. The mix was compacted into a cylindrical mould $(50 \times 25 \mathrm{~mm})$ under a static pressure of $16 \mathrm{MPa}$ and then dried in an oven at $80{ }^{\circ} \mathrm{C}$ for $24 \mathrm{~h}$. Subsequently, the samples were subjected to cycles of immersion in water for $24 \mathrm{~h}$ and subsequent drying at $40{ }^{\circ} \mathrm{C}$ for another $24 \mathrm{~h}$. This cycle was repeated 5, 10, 25, 50 and 100 times on different samples. Mechanical testing showed that the compressive strength reduced from $40 \mathrm{MPa}$, for the simply oven dried samples, to about $20 \mathrm{MPa}$, for the samples subjected to 5 wetting - drying cycles. After the fifth cycle, the compressive strength remained approximately constant, thus implying that the material becomes progressively less sensitive to humidity changes.

Elert et al. [21] proposed the use of alkaline activation for the consolidation of existing earthen buildings. Compressed adobe blocks $(4 \times 4 \times 4 \mathrm{~cm})$ with a soil/water mass ratio of three were impregnated for 20 minutes in three different alkaline solutions of $0.025 \mathrm{~mol} / \mathrm{L} \mathrm{Ca}(\mathrm{OH})_{2}, 5 \mathrm{~mol} / \mathrm{L}$ $\mathrm{NaOH}$ and $5 \mathrm{~mol} / \mathrm{L} \mathrm{KOH}$. The blocks were then stored for 50 days in plastic bags to simulate an insitu consolidation treatment. After that, they were exposed to the atmosphere at a temperature of about $20{ }^{\circ} \mathrm{C}$ and a humidity of about $45 \%$ until their mass became constant. Durability was next evaluated by immersing the treated samples in water and by measuring the time until significant erosion occurred. Results showed that the treatment by $\mathrm{Ca}(\mathrm{OH})_{2}$ did not significantly improve the resistance of the material as these samples almost disintegrated after only $2.5 \mathrm{~h}$ of immersion in water. Conversely, the samples treated with $\mathrm{NaOH}$ and $\mathrm{KOH}$ showed higher resistance to water and withstood significant erosion for almost $48 \mathrm{~h}$.

\section{CONCLUSIONS}

Over the last three decades, the use of raw earth for the construction of buildings has gained interest because of its potentially low environmental impact and reduced costs. If suitably manufactured, raw earth is a viable construction material with low levels of embodied, operational and end-of-life energy. 
A number of modern construction techniques have been developed such as, for example, those employing casted earth or prefabricated earth panels. Further dissemination of these techniques must however overcome important obstacles such as the potential inadequacy of local soils, the low durability of raw earth in wet climates and a lack of knowledge about the energy performance of earth buildings during service life.

This paper has reviewed the above issues and has discussed some recent research about the hydrothermo-mechanical behaviour of raw earth. The first part of the paper has retraced the history of earthen construction and has provided a brief description of the main building techniques. The second part has focused on the key engineering properties of raw earth and their dependency on material, manufacturing and environmental variables. Some basic geotechnical concepts applicable to raw earth construction have also been highlighted. For example, geotechnical knowledge about soil-water retention and the effect of suction on material strength could be exploited to assess the moisture buffering characteristics and vulnerability of earth structures in humid climates. The paper has also discussed a recently proposed "hypercompaction" method for fabricating raw earth at very high pressures up to $100 \mathrm{MPa}$. This manufacturing process can produce unstabilized earth blocks that exhibit strength and stiffness comparable to those of traditional masonry bricks and very little shrinkage upon ambient drying.

\section{REFERENCES}

1. AFNOR (1999). NF P 94-093. Soils: investigation and testing - determination of the compaction characteristics of a soil - Standars Proctor test - Modified Proctor test.

2. ASTM C270 (2004). American Society for Testing and Materials. Standard Specification for Mortar for Unit Masonry.

3. Beckett, C.T.S. and Augarde, C.E. (2012). The effect of humidity and temperature on the compressive strength of rammed earth. In Proceedings of 2nd European Conference on Unsaturated Soils: 287-292. Naples, Italy, 20-22 June 2012, Springer, ISBN: 978-3-642$31342-4$ 
4. Bossink, B.A.G. and Brouwers, H.J.H. (1996). Construction waste: quantification and source evaluation. Journal of Construction and Engineering Management, 122(1): 55-60, ISSN 07339364.

5. Bossink, B.A.G., Brouwers, H.J.H. and Kessel, R.A. van (1996). Financial consequences of construction waste. In Proceedings of International Conference CIB W98: 1-15. Beijing, China, 21-24 October 1996.

6. British Building Regulations (2010). Approved Document E: Resistance to the Passage of Sound, published by the National Building Specification (NBS) part of the Royal Institute of British Architects (RIBA) Enterprises Ltd

7. British Standard 1377 (1990). Methods of test for soils for civil engineering purposes, British Standards Institute, London

8. British Standard 8233 (1999). Sound Insulation and Noise Reduction for Buildings: Code of Practice, British Standards Institute, London

9. Bruno, A. W., Gallipoli, D., Perlot, C., Mendes, J. and Salmon, N. (2015). Mechanical properties of unstabilized earth compressed at high pressures. In Proceedings of 1st International conference on Bio-based Building Materials, 21st - 24th June 2015.

10. Bui, Q.-B., Morel, J.C., Hans, S. and Walker, P. (2014). Effects of moisture content on the mechanical characteristics of rammed earth. Construction and Building Materials, 54: 163169. DOI:10.1016/j.conbuildmat.2013.12.067

11. Bui, Q.B., Morel, J.C., Venkatarama Reddy, B.V. and Ghayad, W. (2008). Durability of rammed earth walls exposed for 20 years to natural weathering. Building and Environment, 44: 912-919. DOI:10.1016/j.buildenv.2008.07.001

12. Bui, Q.-B., Morel, J.C., Hans, S. and Meunier, N. (2009). Compression behaviour of nonindustrial materials in civil engineering by three scale experiments: the case of rammed earth. Materials and Structures, 42(8): 1101-1116.

13. Chilkoti, A. (2012). Mud world. Financial Times, 19 October 2012. http://www.ft.com/cms/s/2/791620e6-13c2-11e2-9ac6-00144feabdc0.html\#axzz2K8Pbgvq1 (last accessed: 19 June 2015) 
14. Cointeraux, F. (1790-1791). École d'architecture rurale. Premier, deuxième, troisième et quatrième cahier. Published by Vezard \& Le Normant.

15. Crowley, M. (1997). Quality control for earth structures. Australian Institute of Building Papers 8:109-118.

16. Dahmen, A. J. (2015). Who's afraid of raw earth? Experimental wall in New England and the environmental cost of stabilization. In Proceedings of the First International Conference on Rammed Earth Construction (ICREC2015): 85-88. Perth, Australia, 10-13 February 2015.

17. Davidovits, J. (2011). Geopolymer chemistry and applications. $3^{\text {rd }}$ ed. Institut Géopolymère; 2011.

18. Deboucha, S. and Hashim, R. (2011). A review on bricks and stabilized compressed earth blocks. Scientific Research and Essays, 6(3): 499-506. DOI: 10.5897/SRE09.356 ISSN 19922248

19. Dierks, K. and Ziegert, C. (2002). Neue Untersuchungen zum Materialverhaltenvon Stampflehm. In Steingass, P.: Moderner Lehmbau (2002). Tagungsband, Fraunhofer IRB.

20. EEA (2010). The European environment state and outlook 2010. Material resources and waste. European Environment Agency, Copenaghen.

21. Elert, K., Pardo, E. S. and Rodriguez-Navarro, C. (2015). Alkaline activation as an alternative method for the consolidation of earthen architecture. Journal of Cultural Heritage 16: 461-469. DOI: 10.1016/j.culher.2014.09.012

22. Eckermann, W. and Ziegert, C. (2006). Auswirkung von Lehmbaustoffen auf die Raumluftfeuchte.

http://www.claytec.de/fileadmin/user_upload/pdf_download/lehmputz_raumklima.pdf accessed online: 22/06/2016

23. Eurostat (2011). Online Statistics. http://www.epp.eurostat.ec.eduropa.eu

24. Guettala, A., Abibsi, A. and Houari, H. (2006). Durability study of stabilized earth concrete under both laboratory and climatic conditions exposure. Construction and Building Materials, 20(3): 119-127. DOI: 10.1016/j.conbuildmat.2005.02.001 
25. Guettala, A. and Guenfoud, M. (1997). Béton de terre stabilisée propriétés physico-mécanique et influence des types d'argiles. Revue La Technique Moderne, 1-2: 21-26

26. Guillaud, H. (2008). Characterization of earthen materials. In: Avrami, E., Guillaud, H., Hardy, M. (Eds), Terra literature review - an overview of research in earthen architecture conservation. Los Angeles (United States): The Getty Conservation Institute: 21-31.

27. Hall, M. and Djerbib, Y. (2004). Moisture ingress in rammed earth: Part 1 - the effect of soil particle-size distribution on the rate of capillary suction. Construction and Building Materials, 18: 269-280. DOI: 10.1016/j.conbuildmat.2003.11.002

28. Houben, H. and Guillaud, H. (1994). Earth Construction, a comprehensive Guide. Intermediate Technology Publications, London, UK.

29. Houben, H. and Guillaud, H. (1996). Earth construction - A comprehensive guide. Second Edition. Intermediate Technology Publications. London, UK.

30. Houben, H. and Guillaud, H. (2006). Traité de construction en terre. Parenthèse, Marseille, France.

31. Jaquin, P.A., Augarde, C.E. and Legrand, L. (2008). Unsaturated characteristics of rammed earth. In Proceedings of 1st European Conference on Unsaturated Soils: 417-422. Durham, UK, 2-4 July 2008, CRC Press/Balkema, ISBN: 978-0-415-47692-8.

32. Jaquin, P.A., Augarde, C.E., Gallipoli, D. and Toll, D.G. (2009). The strength of rammed earth materials. Géotechnique, 59(5): 487- 490. DOI: 10.1680/geot.2007.00129

33. Jiménez Delagado, M.C. and Cañas Guerrero, I. (2007). The selection of soils for unstabilised earth building: A normative review. Construction and Building Materials, 21: 237-251. DOI: 10.1016/j.conbuildmat.2005.08.006

34. Keable, J. (1996). Rammed Earth Structures. A code of Practice. Intermediate Technology Publications, London, UK.

35. Kebao, R. and Kagi, D. (2012). Integral admixtures and surface treatments for modern earth buildings. Modern Earth Buildings 256-281. DOI:10.1533/9780857096166.2.256. 
36. Kemp B (2000) Soil (including mud-brick architecture). In: Nicholson, P.T., Shaw, I. (Eds), Ancient Egyptian materials and technology. Cambridge University Press: 78-103.

37. Kouakou, C.H. and Morel, J.C. (2009). Strength and elasto-plastic properties of non-industrial materials manufactured with clays as a natural binder. Applied Clay Science, 44: 27-34. DOI: 10.1016/j.clay.2008.12.019

38. Langenbach, R. (2004). Soil Dynamics and the Earthquake Destruction of the Arg-e Bam. Iranian Journal of Seismology and Earthquake Engineering, 5(4):133-151.

39. Lawson, B. and Rudder, D. (1996). Building Materials, Energy and the Environment: Towards Ecologically Sustainable Development. Royal Australian Institute of Architects, 135 pages.

40. Lax, C. (2010). Life cycle assessment of rammed earth. Masters thesis, University of Bath, United Kingdom.

41. Little, B. and Morton, T. (2001). Building with earth in Scotland: innovative design and sustainability. Scottish Executive Central Research Unit Publication.

42. Lucas, R. (1918). Ueber das Zeitgesetz des Kapillaren Aufstiegs von Flussigkeiten. Kolloid Z., 23:15:22.

43. Maniatidis, V. and Walker, P. (2003). A Review of Rammed Earth Construction - DTi Partners in Innovation Project 'Developing Rammed Earth for UK Housing'. Natural Building Technology Group, University of Bath, UK.

44. McGregor, F., Heath, A., Fodde, E. and Shea, A. (2014). Conditions affecting the moisture buffering measurement performed on compressed earth blocks. Building and Environment 75: 11-18. DOI: 10.1016/j.buildenv.2014.01.009.

45. McGregor, F., Heath, A., Maskell, D., Fabbri, A. and Morel, J.C. (2016). A review on the buffering capacity of earth building materials. Proceedings of the Institution of Civil Engineers - Construction Materials. DOI: 10.1680/jcoma.15.00035

46. McHenry, P. G. (1984). Adobe and Rammed Earth Buildings. Design and Construction. Wiley Interscience Publication, New York, USA. 
47. Morel J.C., Pkla, A., Walker, P. (2007). Compressive strength testing of compressed earth blocks. Construction and Building Materials 21 (2007) 303-309. DOI: 10.1016/j.conbuildmat.2005.08.021

48. Norton, J. (1997). Building with Earth. A handbook. Second Edition, Intermediate Technology Publications, London, UK.

49. OECD (2003). Environmentally Sustainable Buildings: Challenges and Policies.

50. Olivier, M., Mesbah, A., (1986). Le matériau terre: Essai de compactage statique pour la fabrication de briques de terre compressées. Bulletin de liaison du Laboratoire des Ponts et Chaussé, Paris, France, 1986, $146: 37-43$.

51. Radanovic, J. (1996). Design Criteria for Reinforced Stabilised Earth Structures, University of Western Australia, Crawley, Australia.

52. Röhlen, U. and Ziegert, C. (2013). Construire en terre crue. Groupe Moniteur, Éditions du moniteur, Paris, France. ISBN : 9782-281-11567-3.

53. SAZS 724 (2001). Zimbabwe Standard. Rammed Earth Structures. Standards Association of Zimbabwe, Harare, Zimbabwe.

54. Slaty, F., Khury, H., Rahier, H. and Wastiels, J. (2015). Durability of alkali activated cement produced from kaolinitic clay. Applied Clay Science 104: 229-237. DOI: 10.1016/j.clay.2014.11.037

55. Schrader, C. A. (1981). Rammed Earth Construction: A re-emerging Technology. Proceedings $6^{\text {th }}$ Natural Passive Solar Conference.

56. Szalay, A. Z.-Z. (2007). What Is Missing from the Concept of the New European Building Directive? Building and Environment, 42(4): 1761-1769.

57. Washburn, E.W. (1921). The dynamics of capillary flow. Physical Review, 17(3):273.

58. Worrell, E., Price, L., Martin, N., Hendriks, C., and Meida, L. O. (2001). Carbon dioxide emissions from the global cement industry. Annual Review of Energy and the Environment, 26(1), 303-329. DOI: 10.1146/annurev.energy.26.1.303 
59. Wu, F., Li, G., Li, H.-N. and Jia, J.-Q. (2012). Strength and stress-strain characteristics of traditional adobe block and masonry. Materials and structures, 46: 1449-1457. DOI: 10.1617/s11527-012-9987-y 


\section{TABLES AND CAPTIONS}

Table 1 Main properties of material tested by Bruno et al. [9]

\begin{tabular}{lcc}
\hline \multicolumn{3}{c}{ Particle size distribution } \\
\hline Gravel & $>2 \mathrm{~mm}$ & $0.4 \%$ \\
Sand & $0.063 \mathrm{~mm}-2 \mathrm{~mm}$ & $40.4 \%$ \\
Silt & $0.002 \mathrm{~mm}-0.063 \mathrm{~mm}$ & $42.9 \%$ \\
Clay & $<0.002 \mathrm{~mm}$ & $16.3 \%$ \\
\hline \multicolumn{3}{c}{ Plasticity properties } \\
\hline Liquid limit, $\mathrm{w}_{\mathrm{L}}$ & $33.0 \%$ \\
Plastic limit, $\mathrm{w}_{\mathrm{P}}$ & $20.1 \%$ \\
Plasticity index, $\mathrm{I}_{\mathrm{P}}$ & $12.9 \%$ \\
Activity, A & 0.79 \\
\hline \multicolumn{2}{c}{} \\
\hline Specific gravity, Gs & Soil solids \\
\hline
\end{tabular}

Table 2 Compressive strength of different masonry materials

\begin{tabular}{lcc}
\hline \multirow{2}{*}{ Material } & \multicolumn{2}{c}{ Compressive strength (MPa) } \\
\cline { 2 - 3 } & Min. & Max. \\
\hline Hypercompacted unstabilized earth [9] & 4.1 & 10.2 \\
Compacted stabilized earth [25] & 5.2 & 12.9 \\
Standard masonry bricks [2] & 6.9 & 27.6 \\
\hline
\end{tabular}

Table 3 Grain size distribution of materials tested by Bui et al. [10]

\begin{tabular}{lcccc}
\hline & Clay & Silt & Sand & Gravel \\
\hline Earth A & $5 \%$ & $30 \%$ & $49 \%$ & $16 \%$ \\
Earth B + 2\% NHL & $4 \%$ & $35 \%$ & $59 \%$ & $2 \%$ \\
Earth C & $9 \%$ & $38 \%$ & $50 \%$ & $3 \%$ \\
\hline
\end{tabular}




\section{FIGURES AND CAPTIONS}

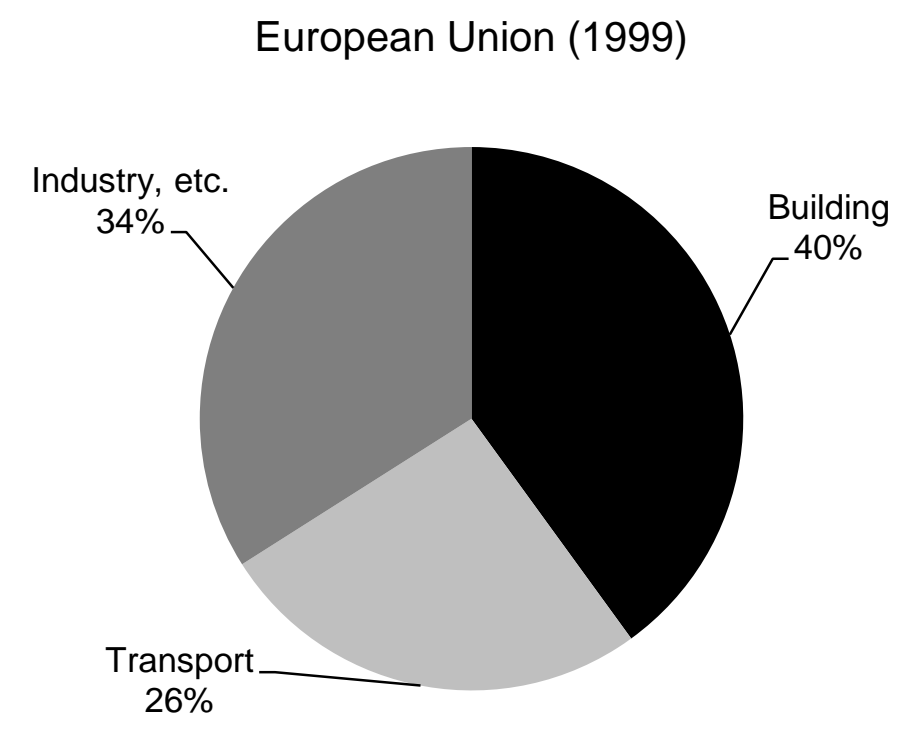

United States (2000)

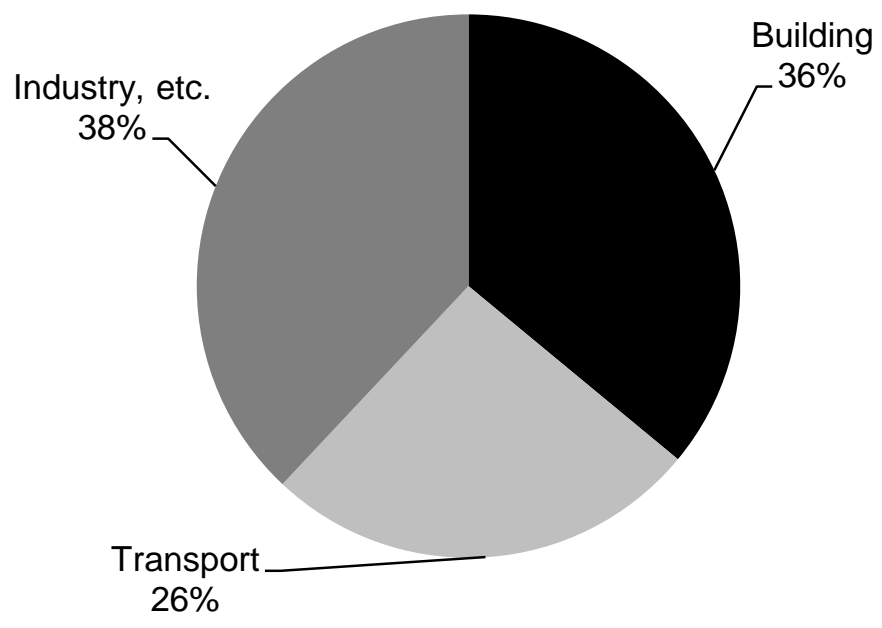

Fig. 1 Energy consumption by sectors in Europe and the United States (after OECD [49]) 


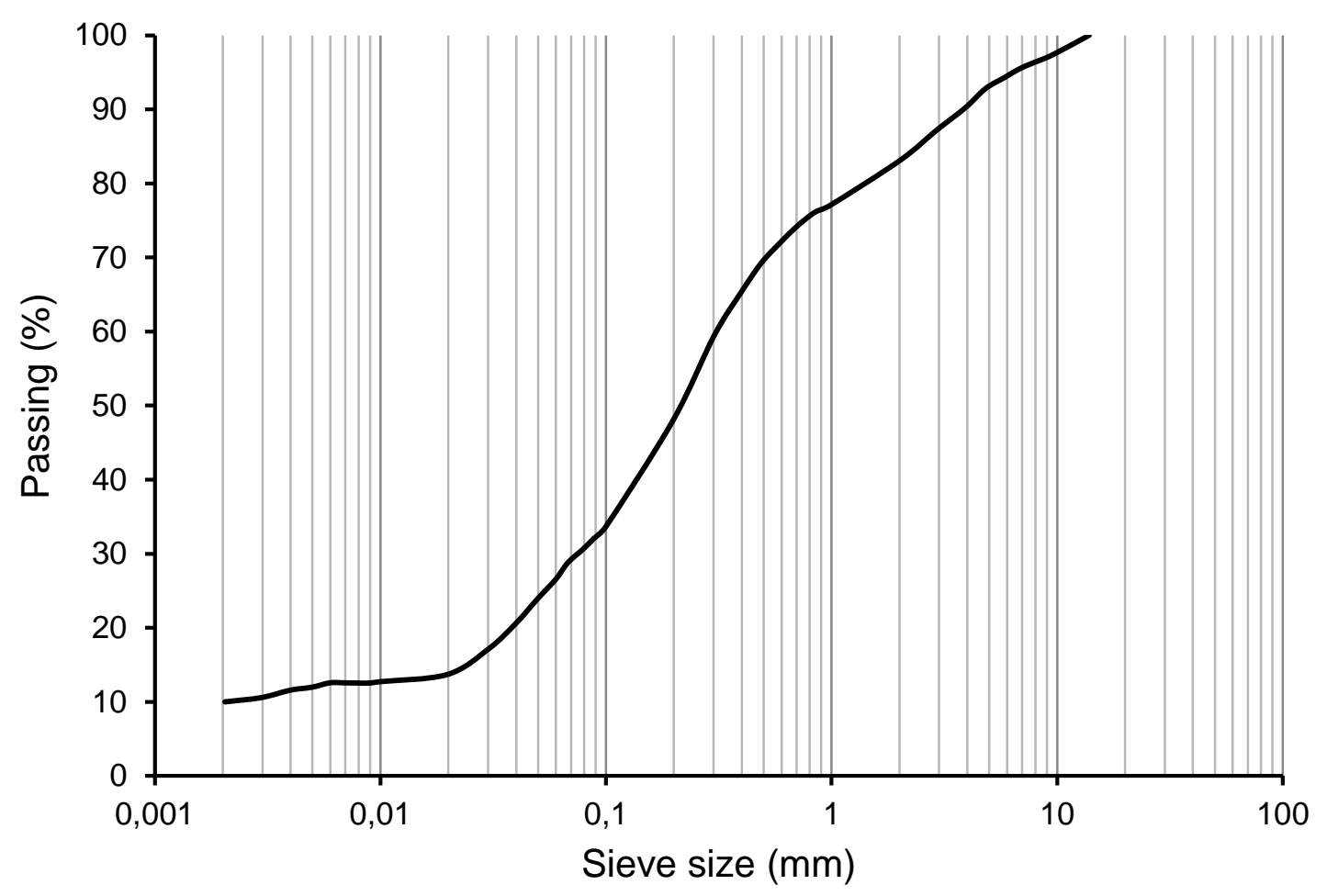

Fig. 2 Typical particle size distribution for raw earth construction (after Jaquin et al. [32]) 


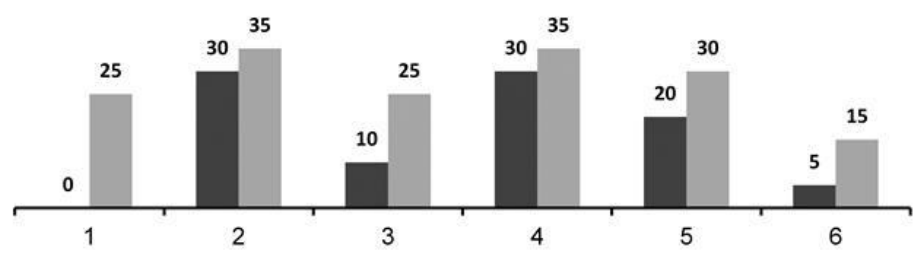

b) silt

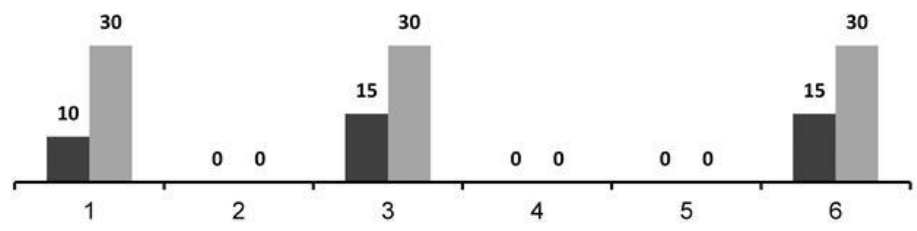
c) sand and gravel
- Lower limits
=Upper limits

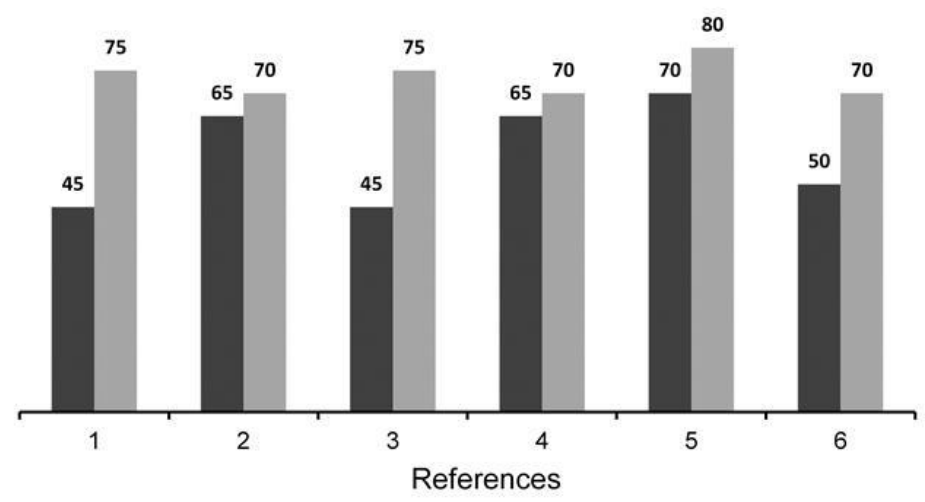

1. Houben and Guillaud [28]; 2. McHenry [46]; 3. Norton [48]; 4. Radanovic [51]; 5. Schrader [55]; 6. SAZS 724 [53].

Fig. 3 Recommended lower and upper proportions of a) clay, b) silt and c) sand and gravel in earthen materials according to various authors 


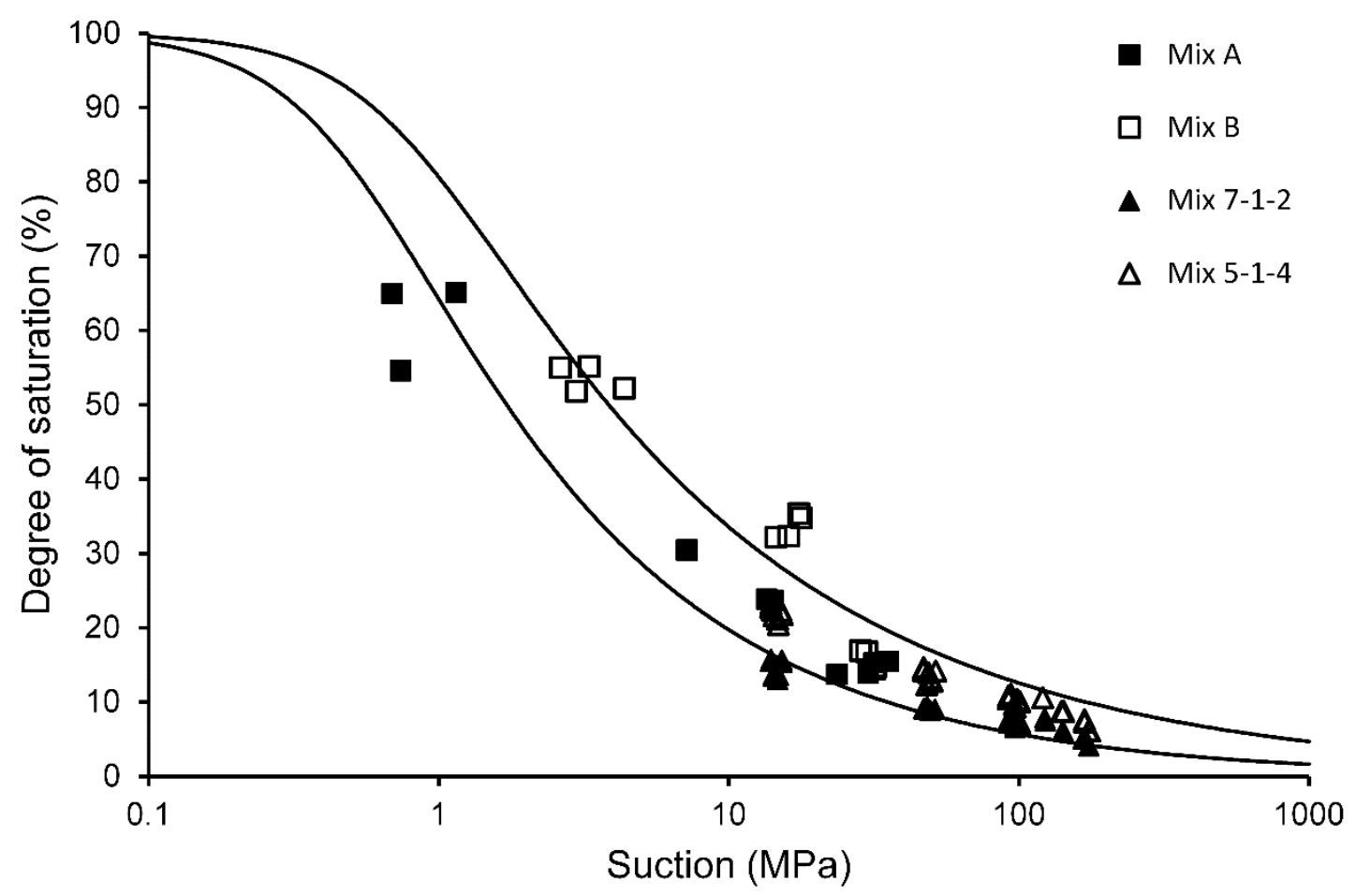

Fig. 4 Drying curves for fine earth (hollow markers) and coarse earth (full markers)

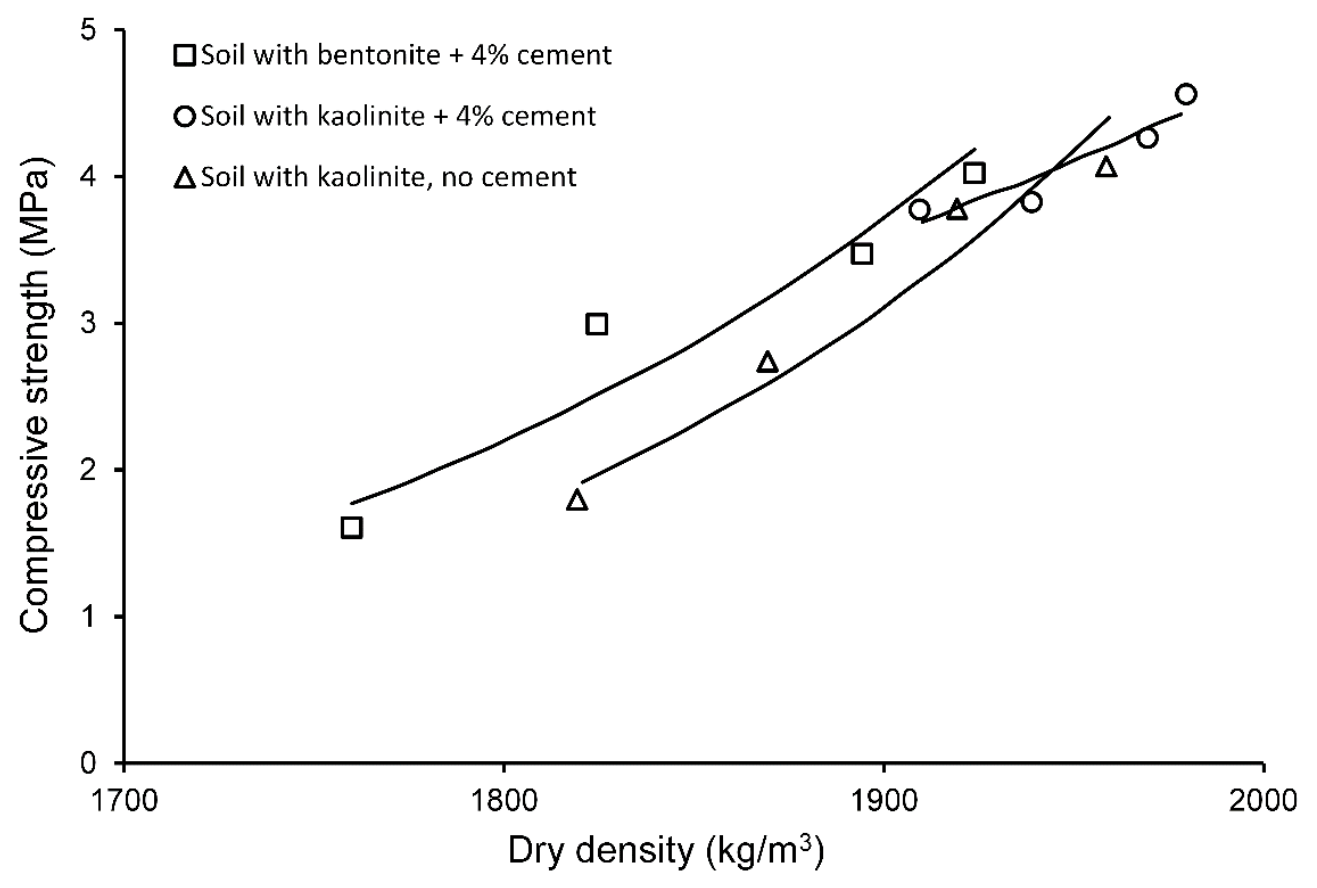

Fig. 5 Variation of compressive strength with dry density (after Morel et al. [47]) 


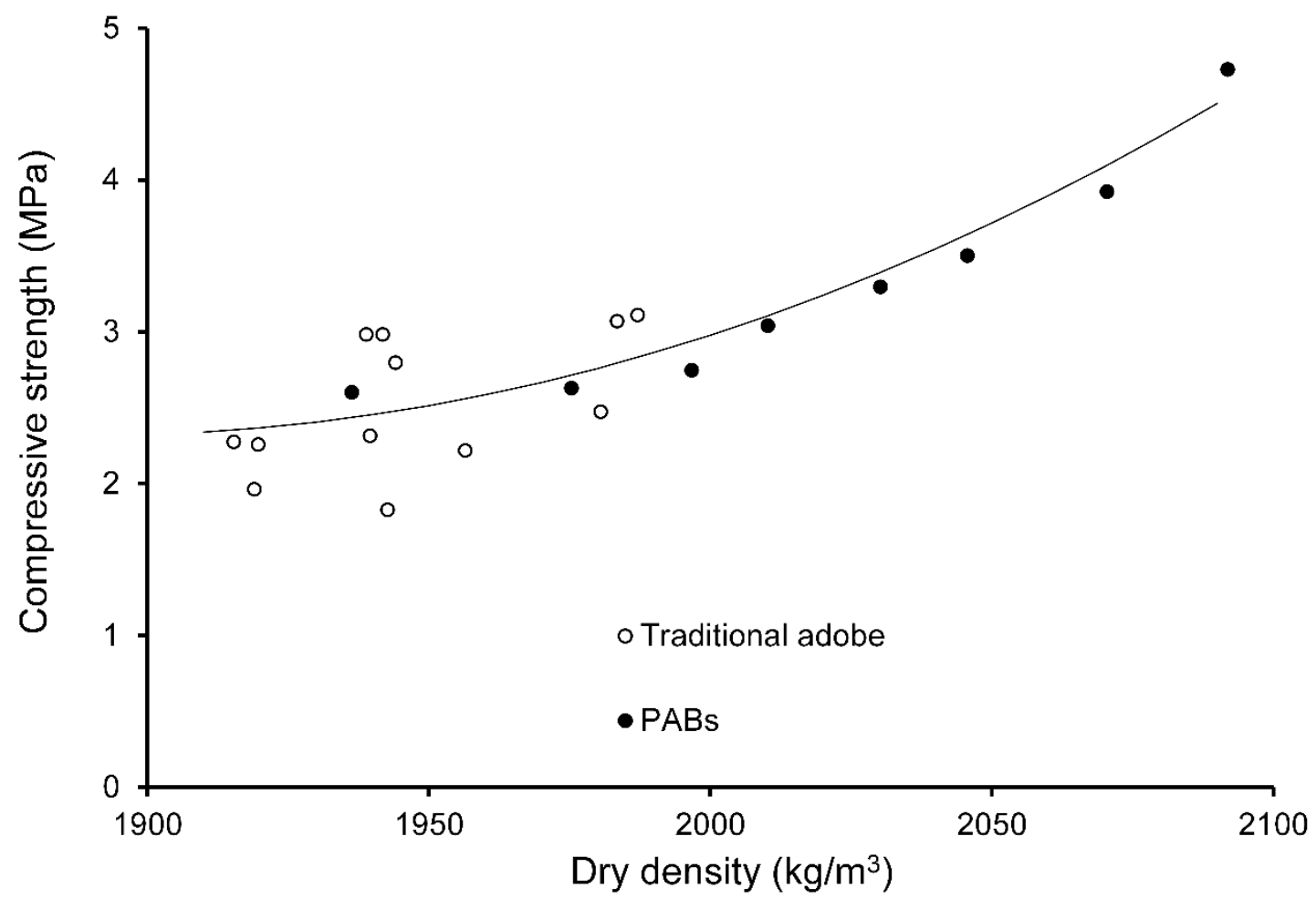

Fig. 6 Variation of compressive strength with dry density (after Kouakou and Morel [37])

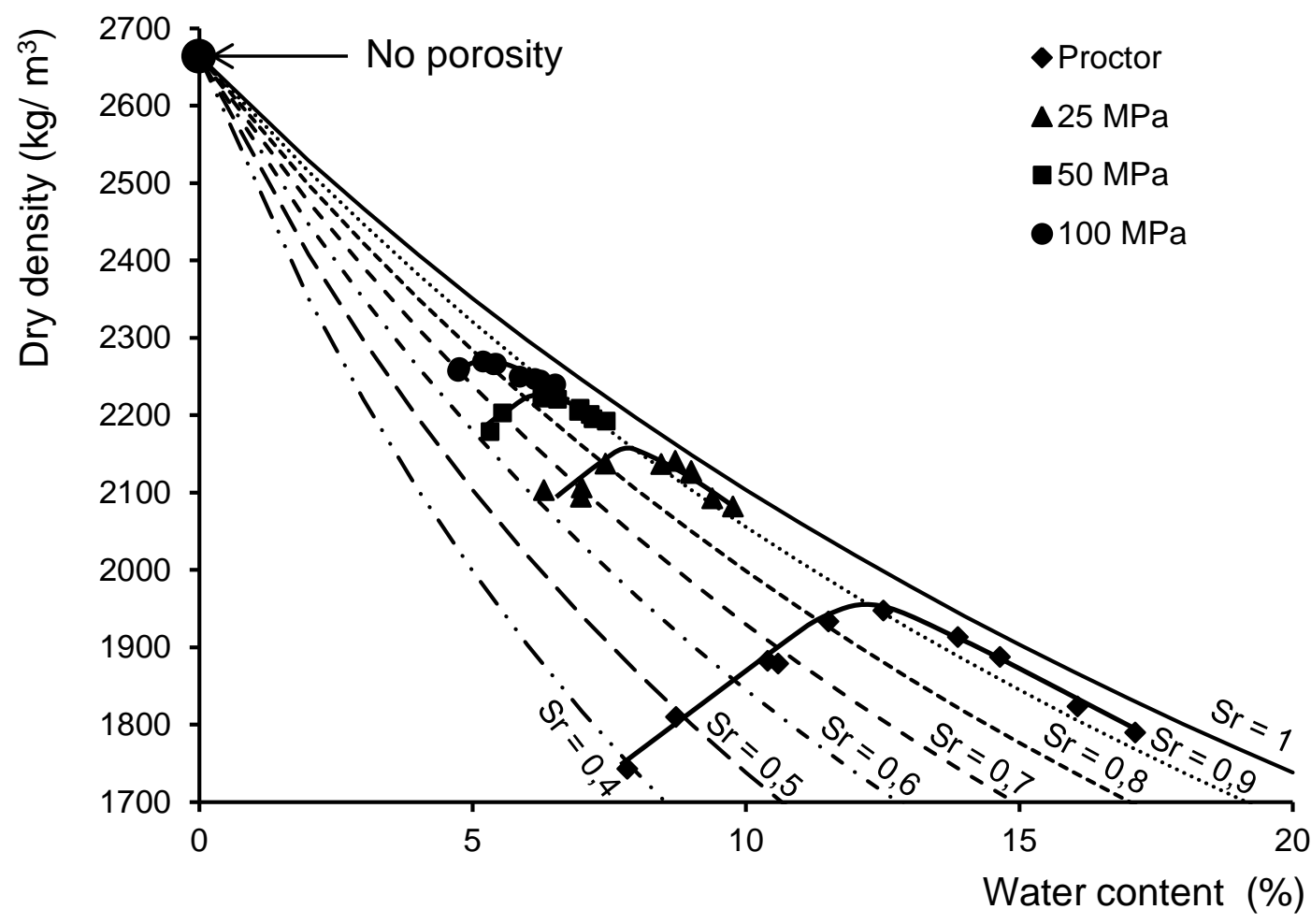

Fig. 7 Compaction curves at 25, 50 and $100 \mathrm{MPa}$ together with standard Proctor (after Bruno et al. [9]) 


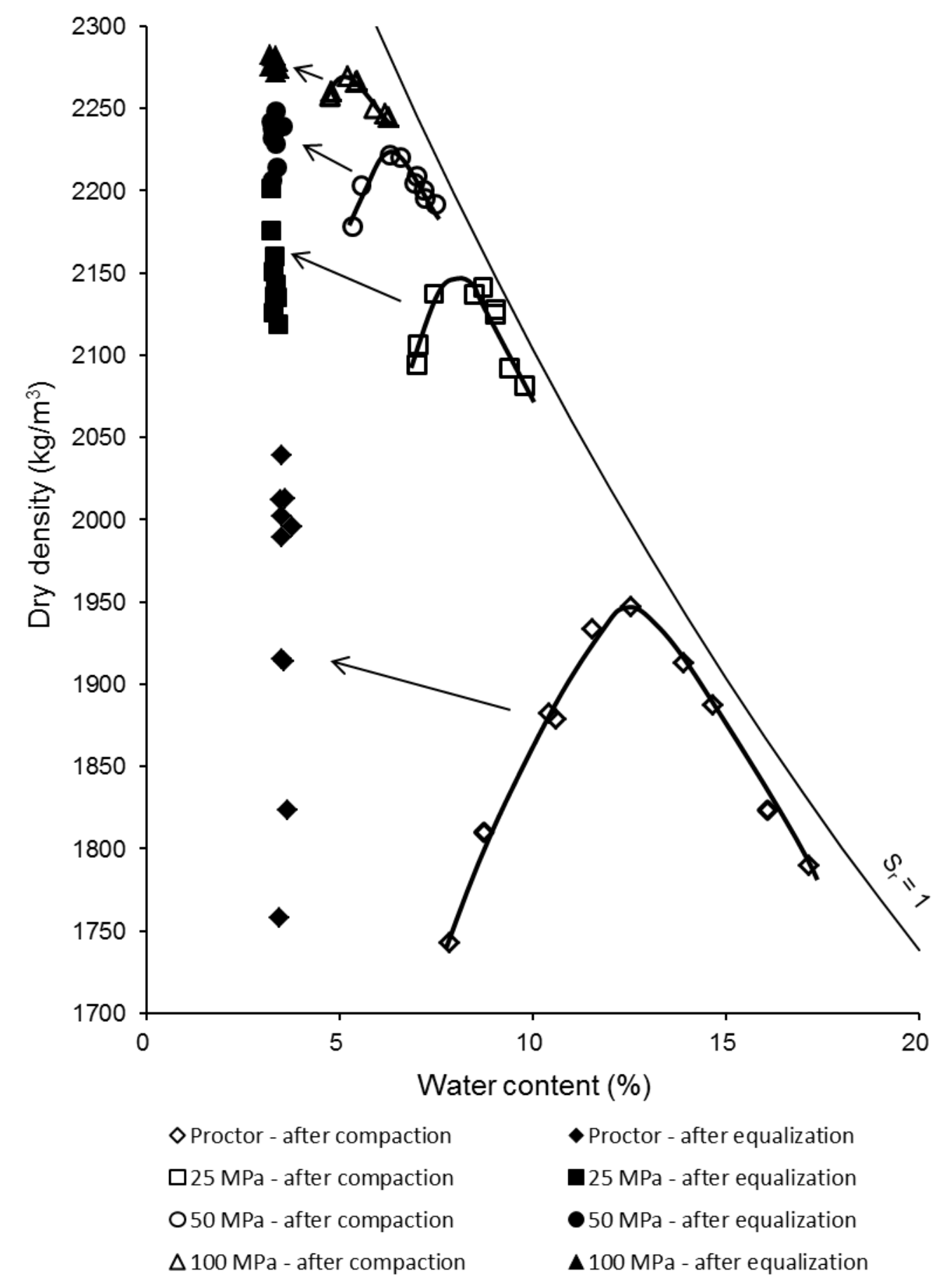

Fig. 8 Change in dry density and water content during equalization 


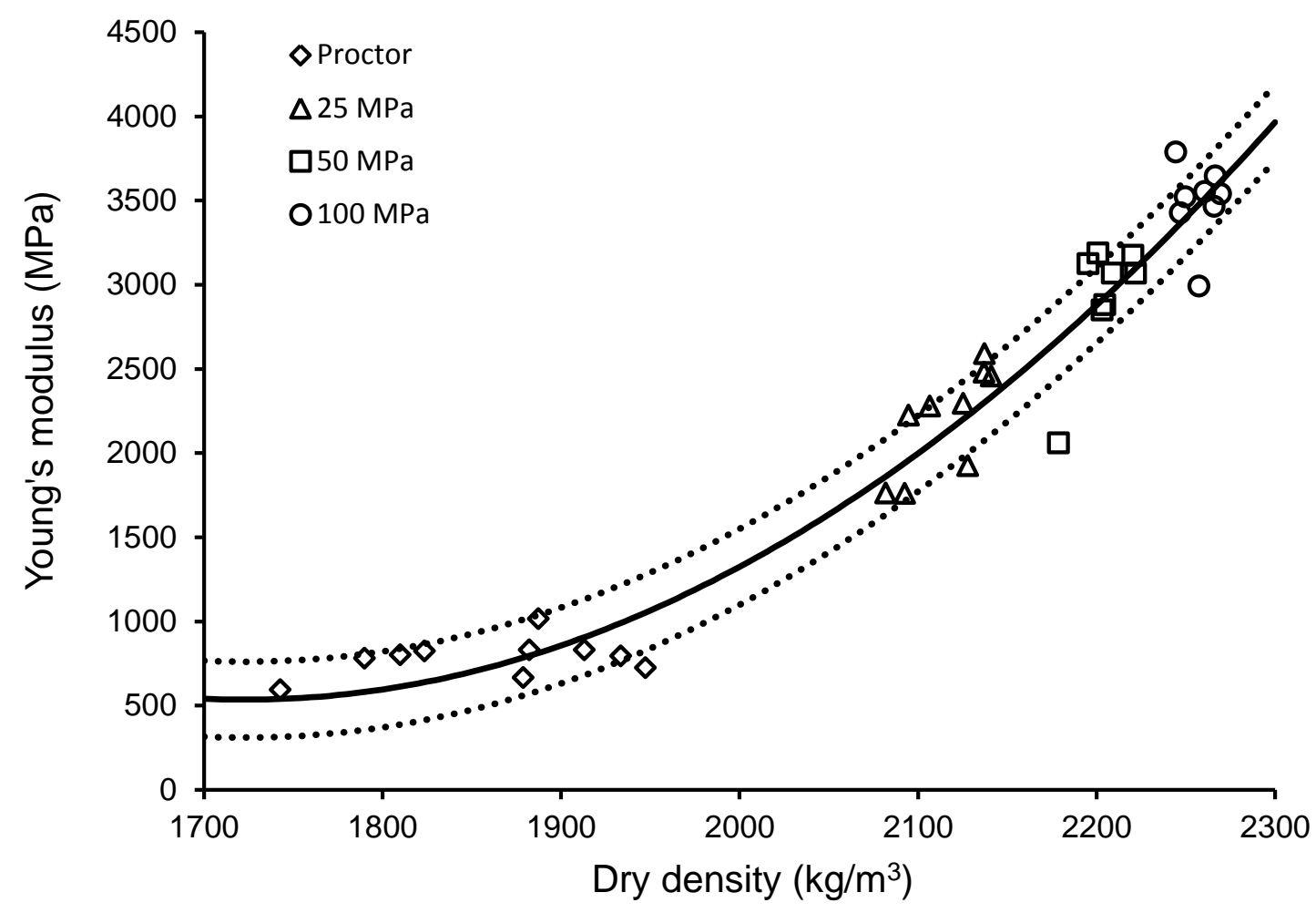

Fig. 9 Variation of Young's modulus with dry density (after Bruno et al. [9])

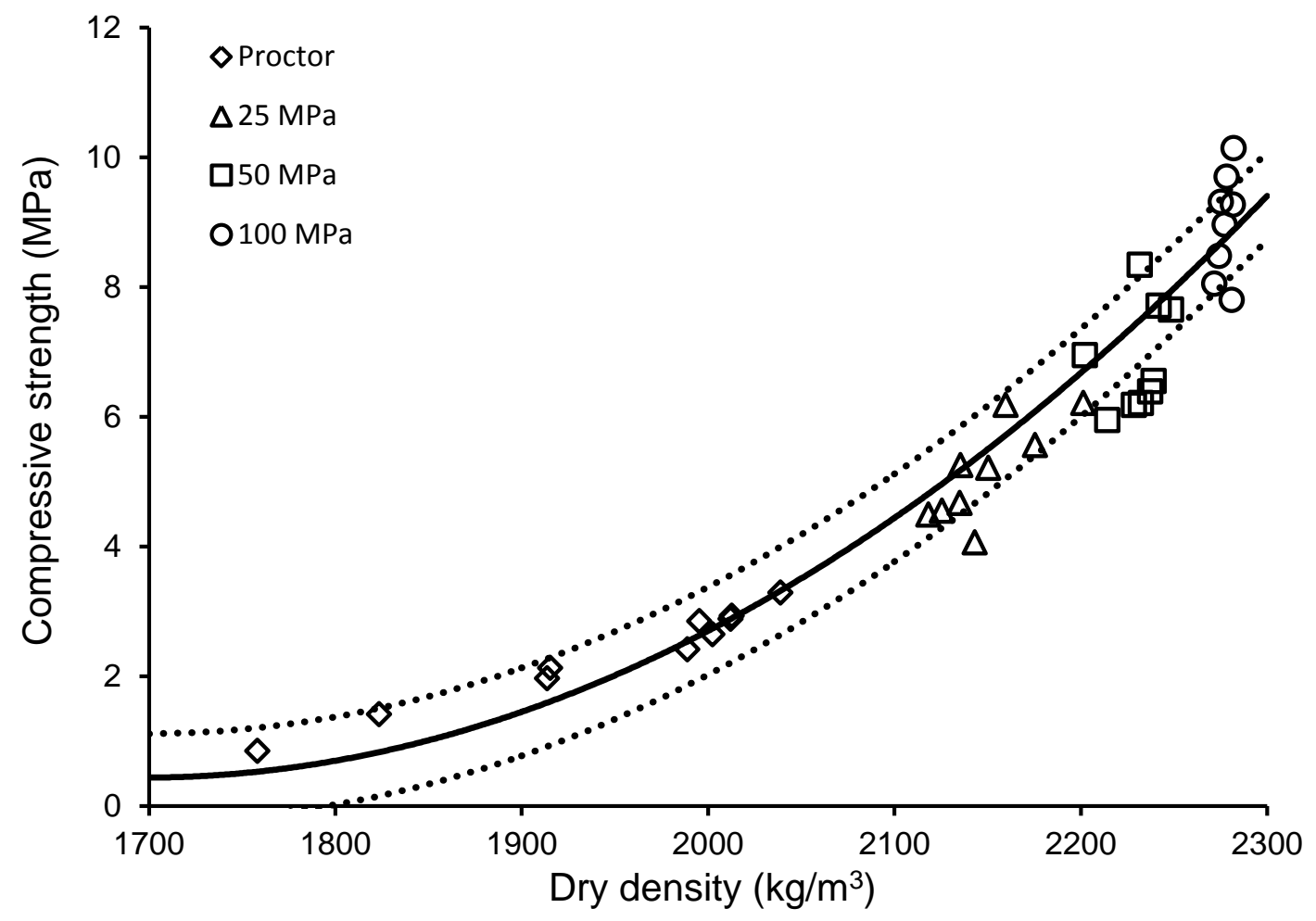

Fig. 10 Variation of compressive strength with dry density (after Bruno et al. [9]) 


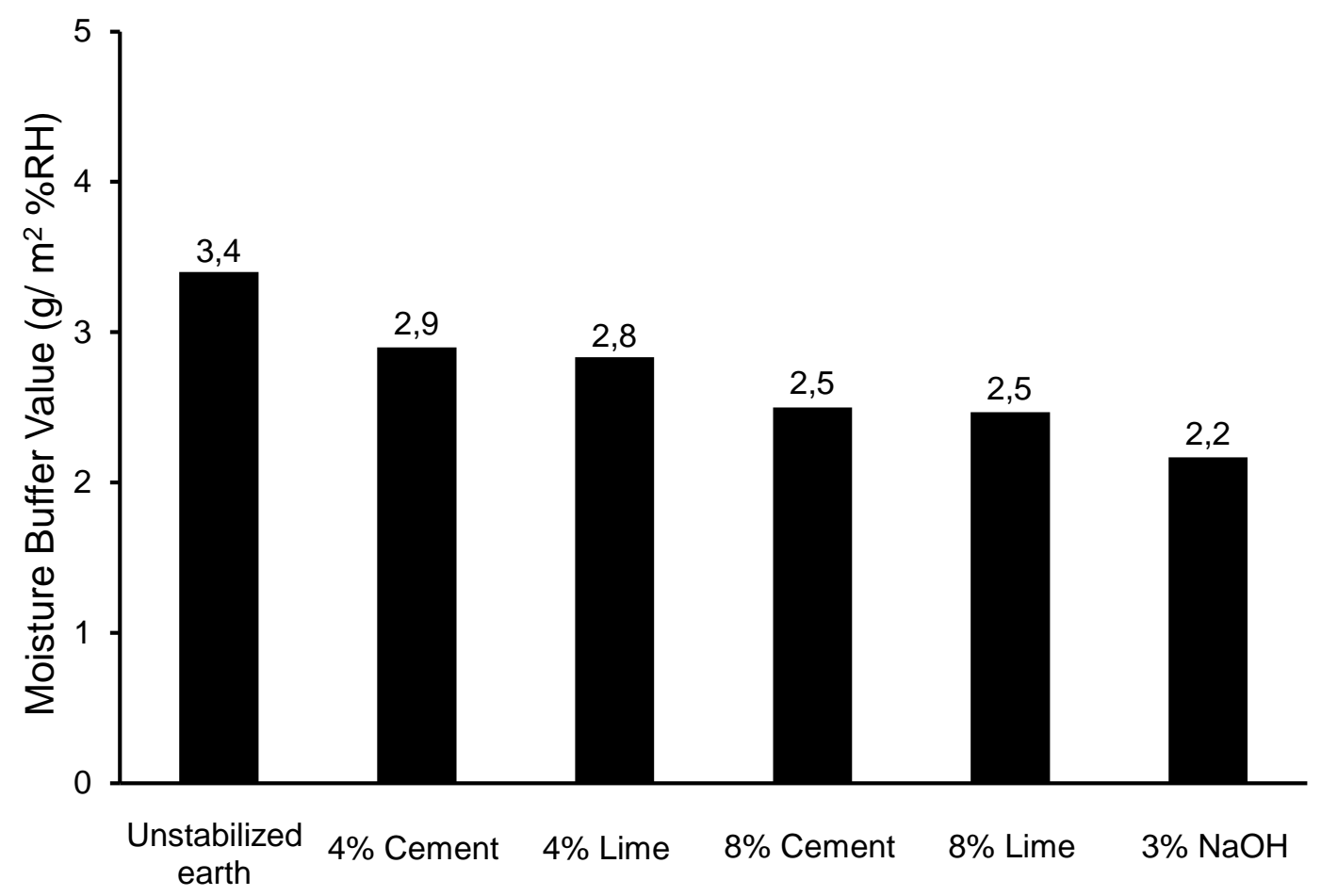

Fig. $11 \mathrm{MBVs}$ of unstabilized and stabilised earthen samples (after McGregor et al. [44])

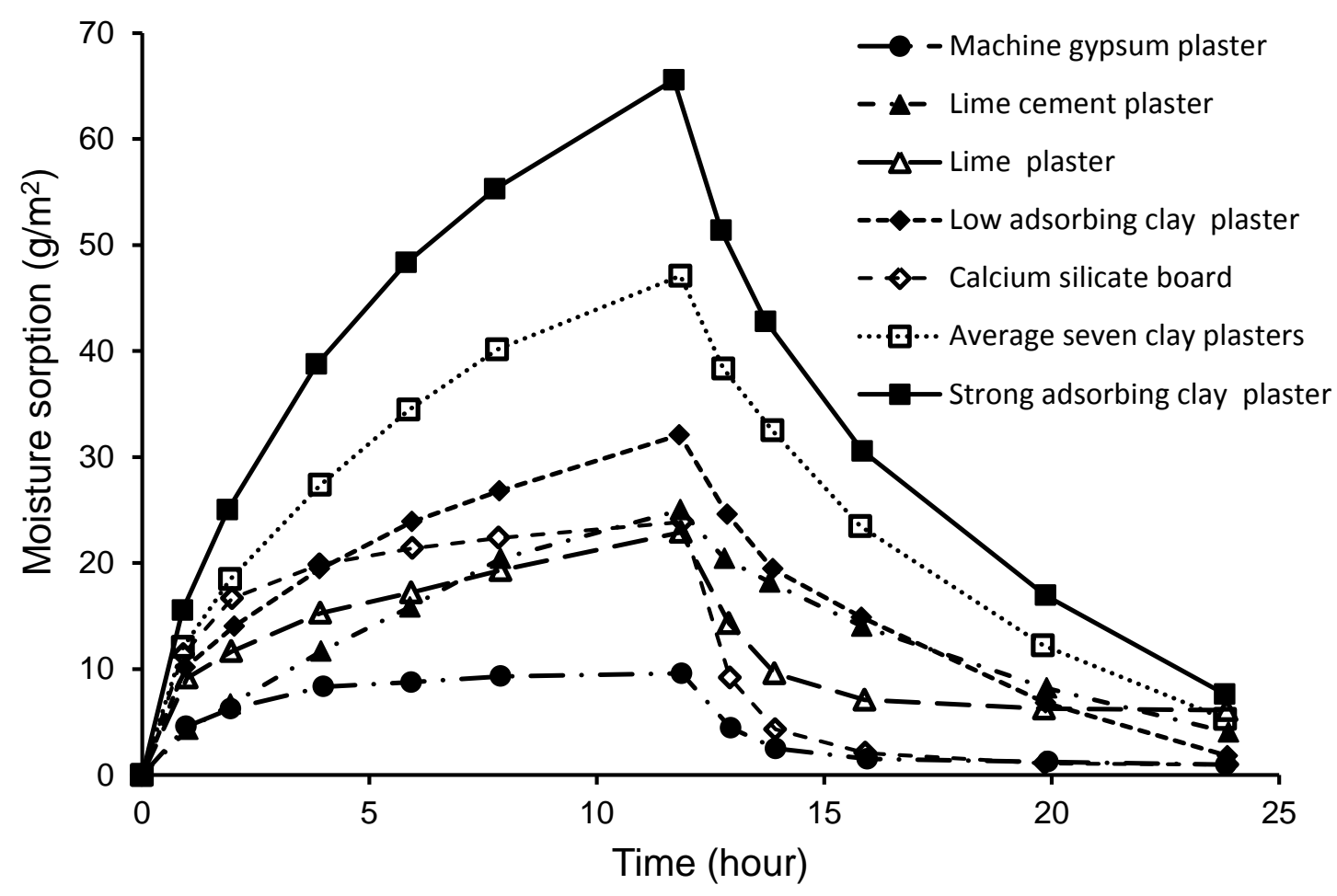

Fig. 12 Moisture sorption of traditional plasters and clay plasters (after Eckermann and Ziegert [22]) 


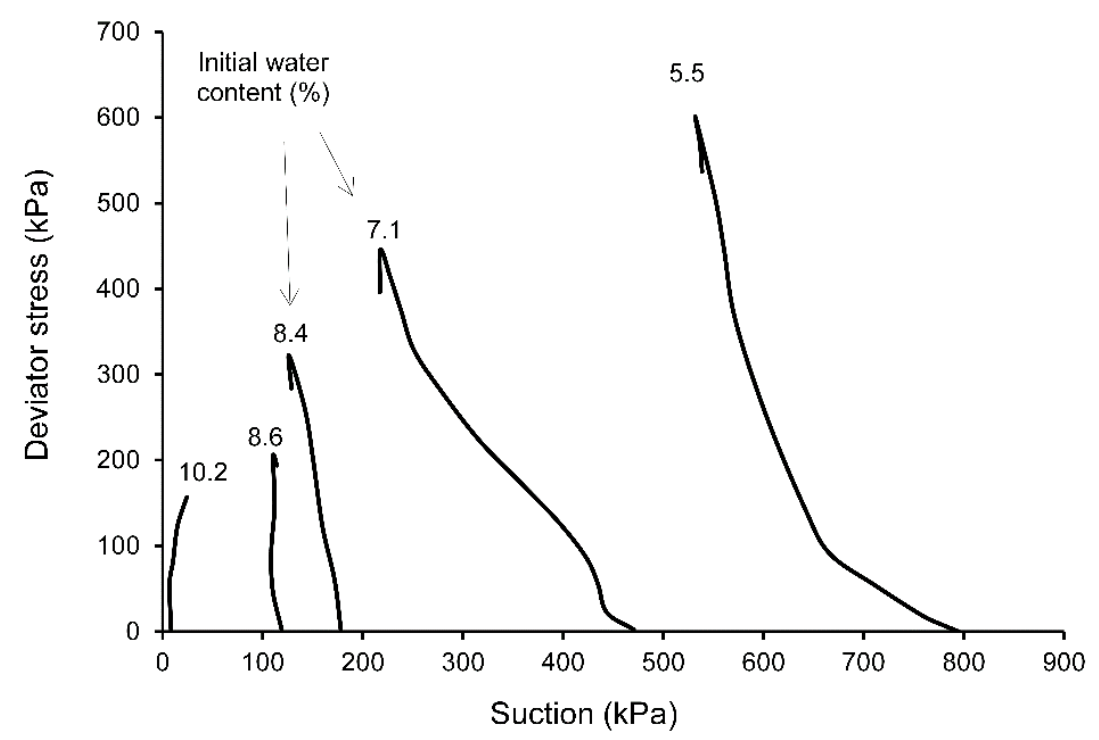

Fig. 13 Deviator stress vs suction during unconfined compression tests at constant water content with suction measurement (after Jaquin et al. [32])

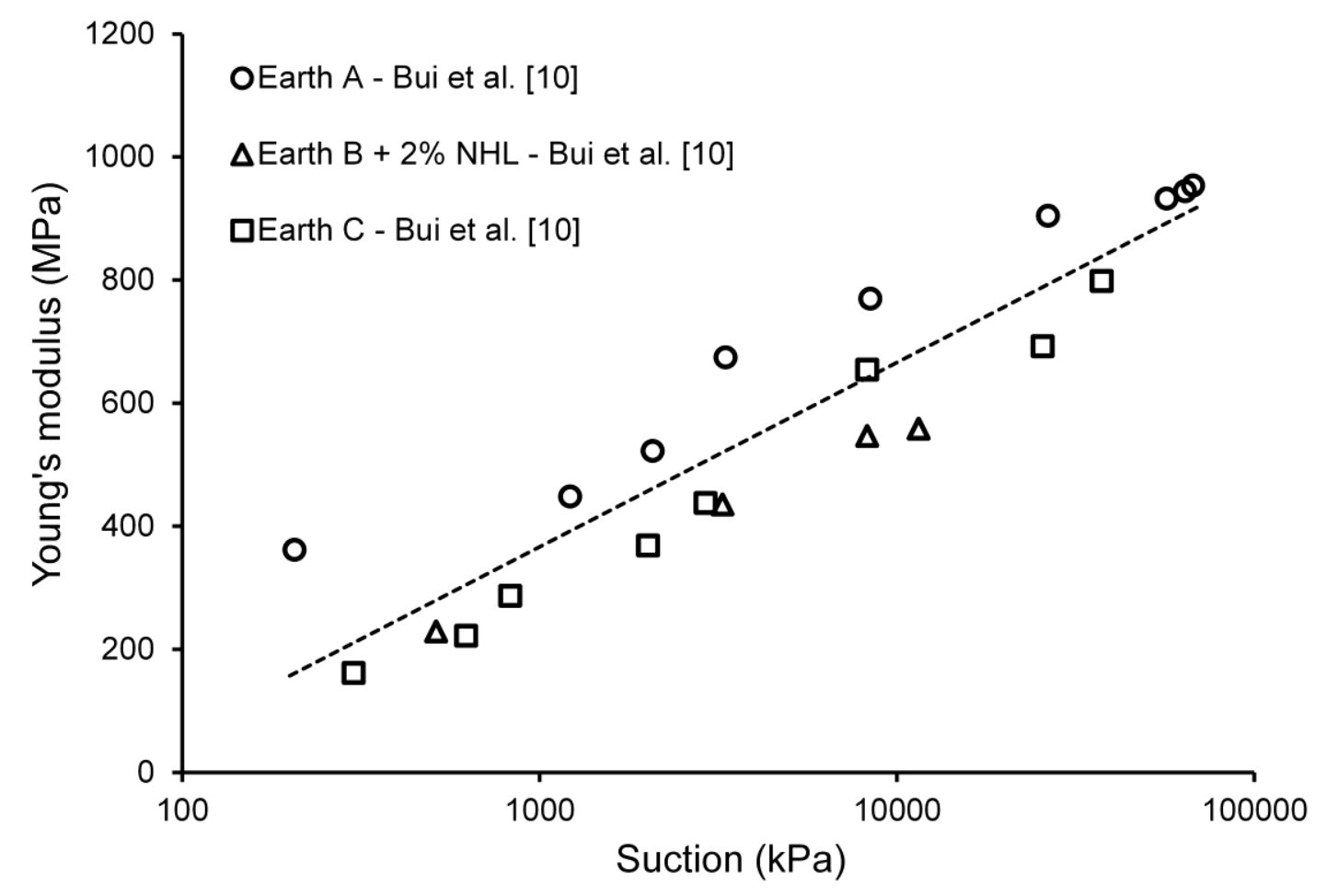

Fig. 14 Variation of Young's modulus with suction (after Bui et al. [10]) 


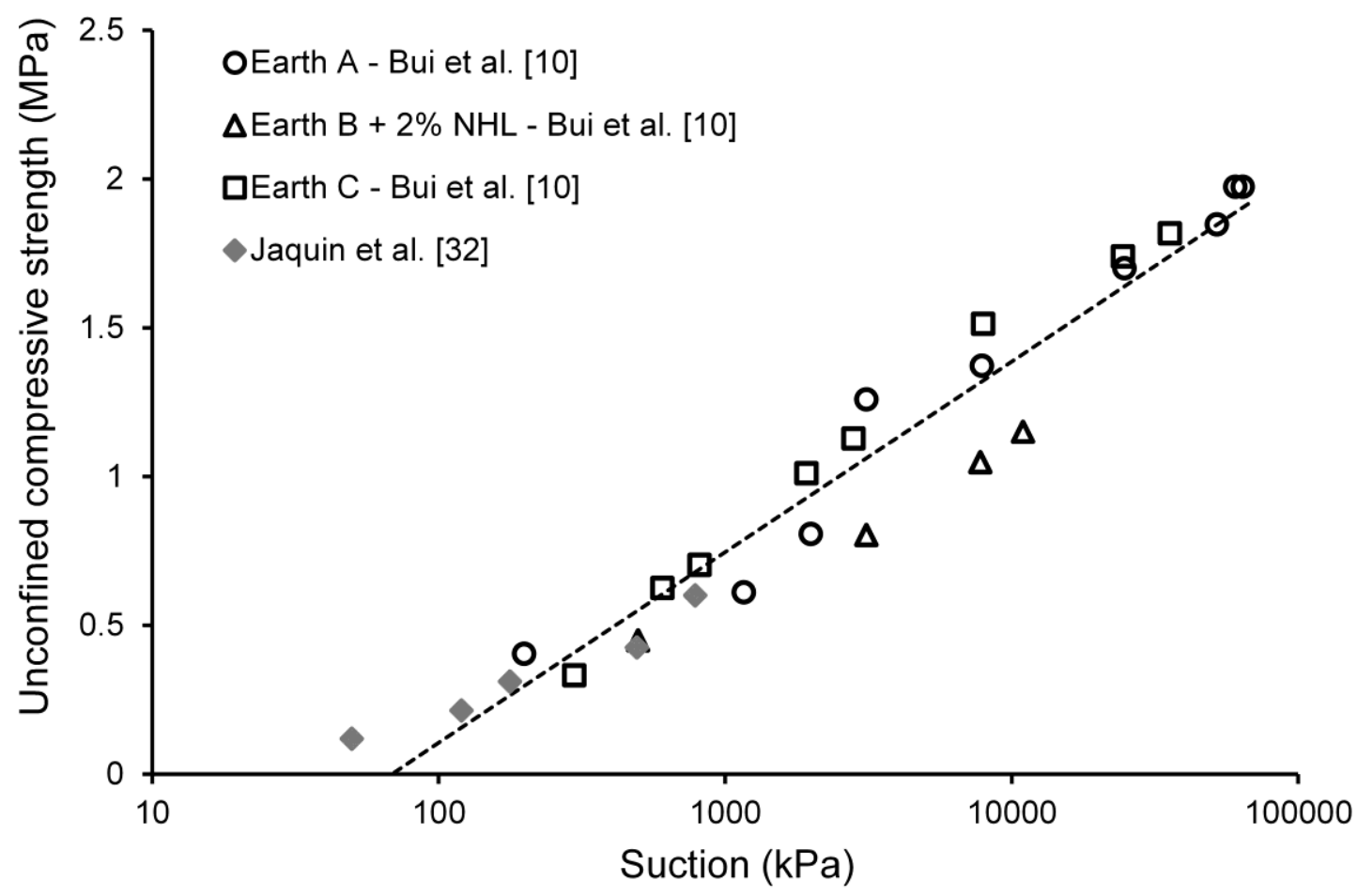

Fig. 15 Variation of unconfined compressive strength with suction (after Bui et al. [10])

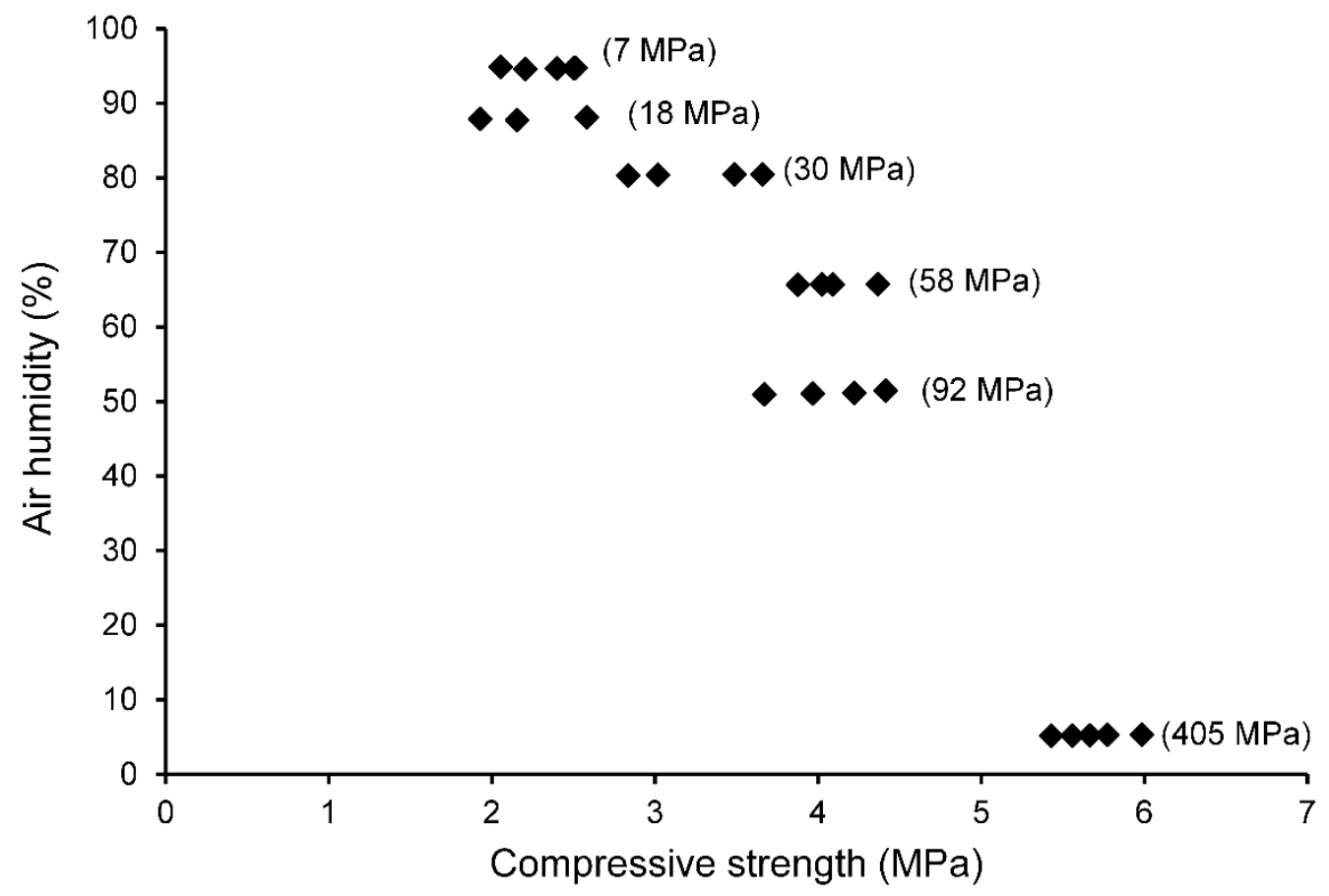

Fig. 16 Variation of unconfined compressive strength with air humidity and suction (after Dierks and Ziegert [19]) 


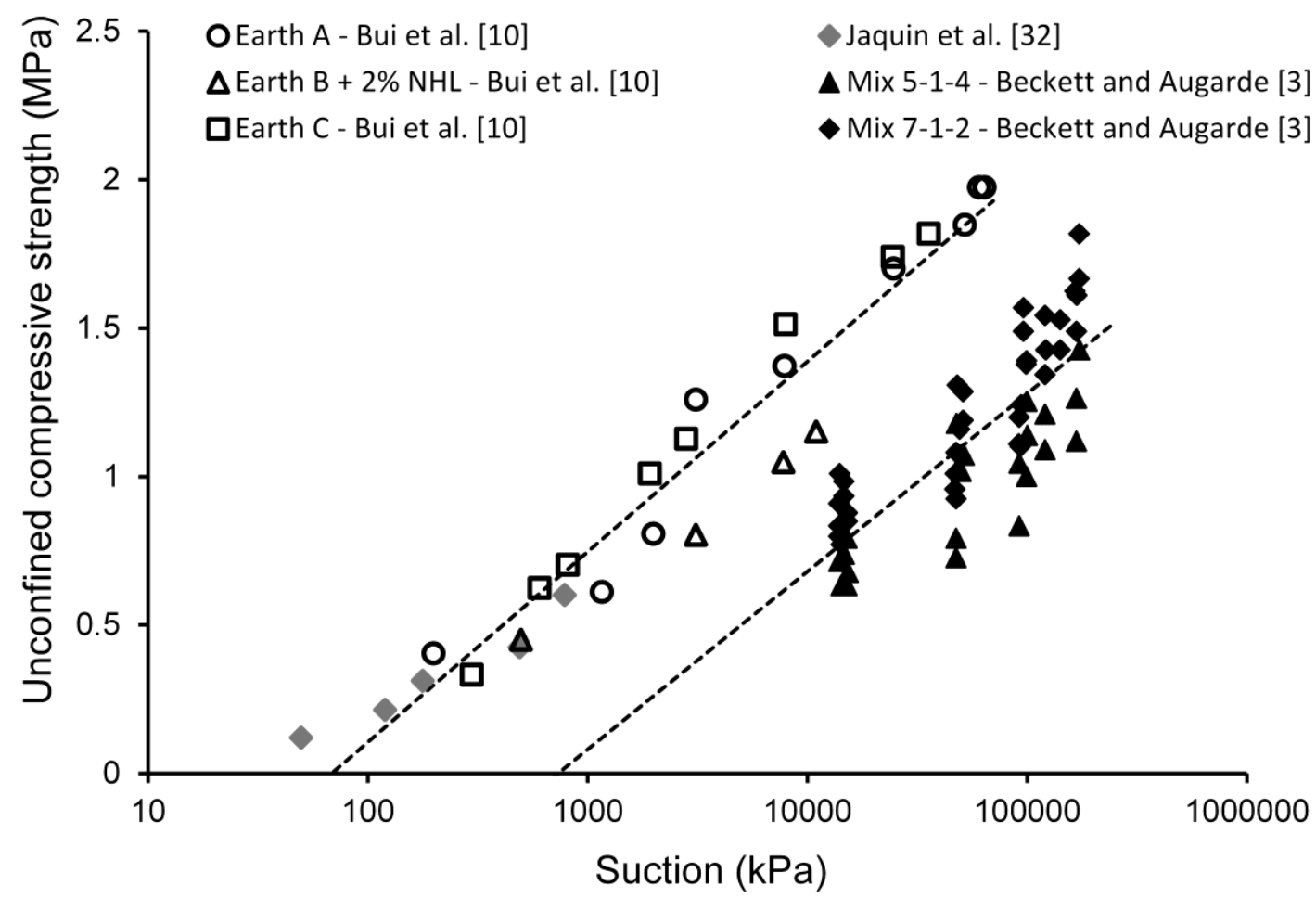

Fig. 17 Variation of unconfined compressive strength with suction: comparison between Bui et al. [10], Jaquin et al. [32] and Beckett and Augarde [3]

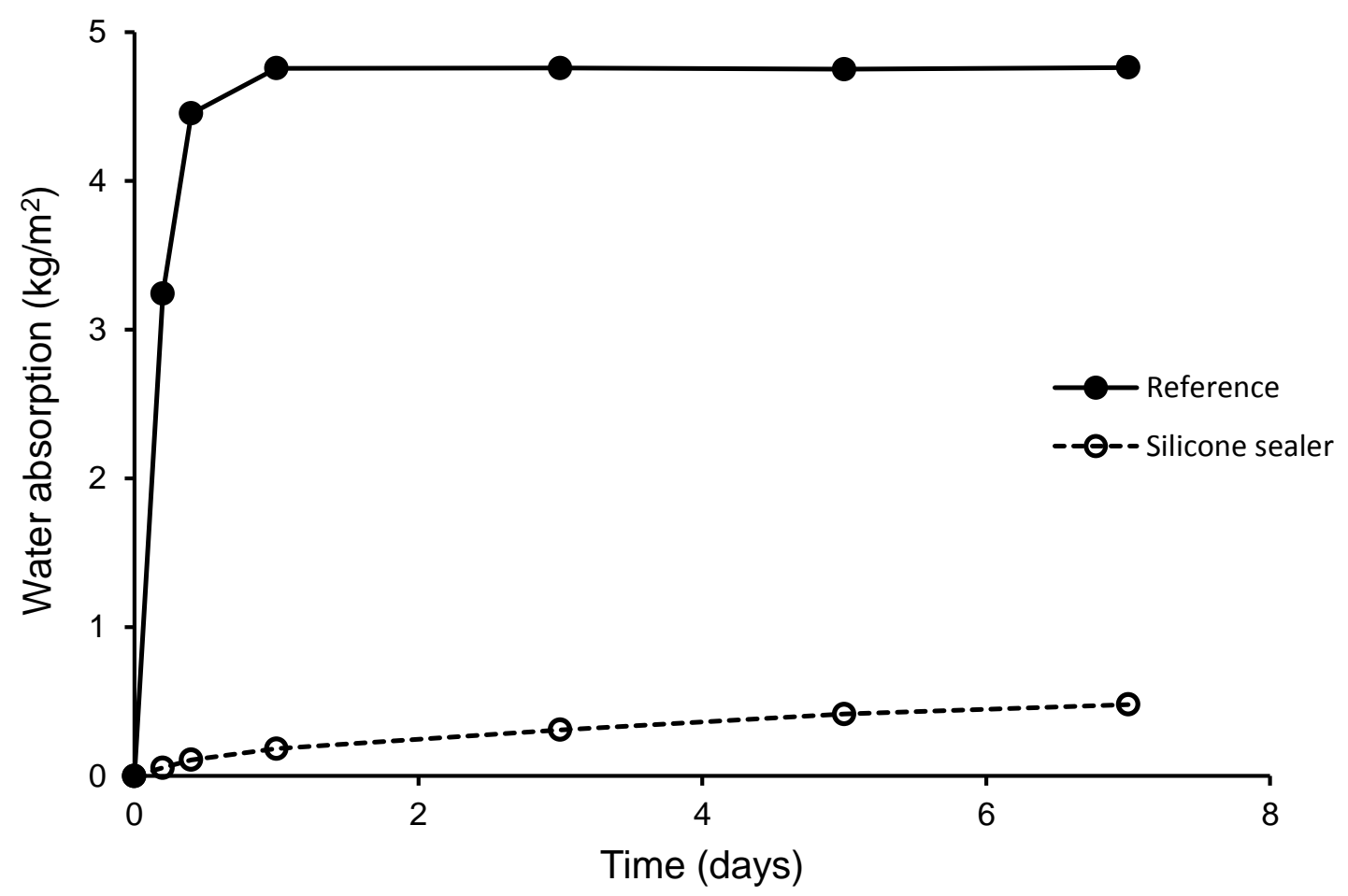

Fig. 18 Water absorption of a rammed earth substrate (after Kebao and Kagi [35]) 


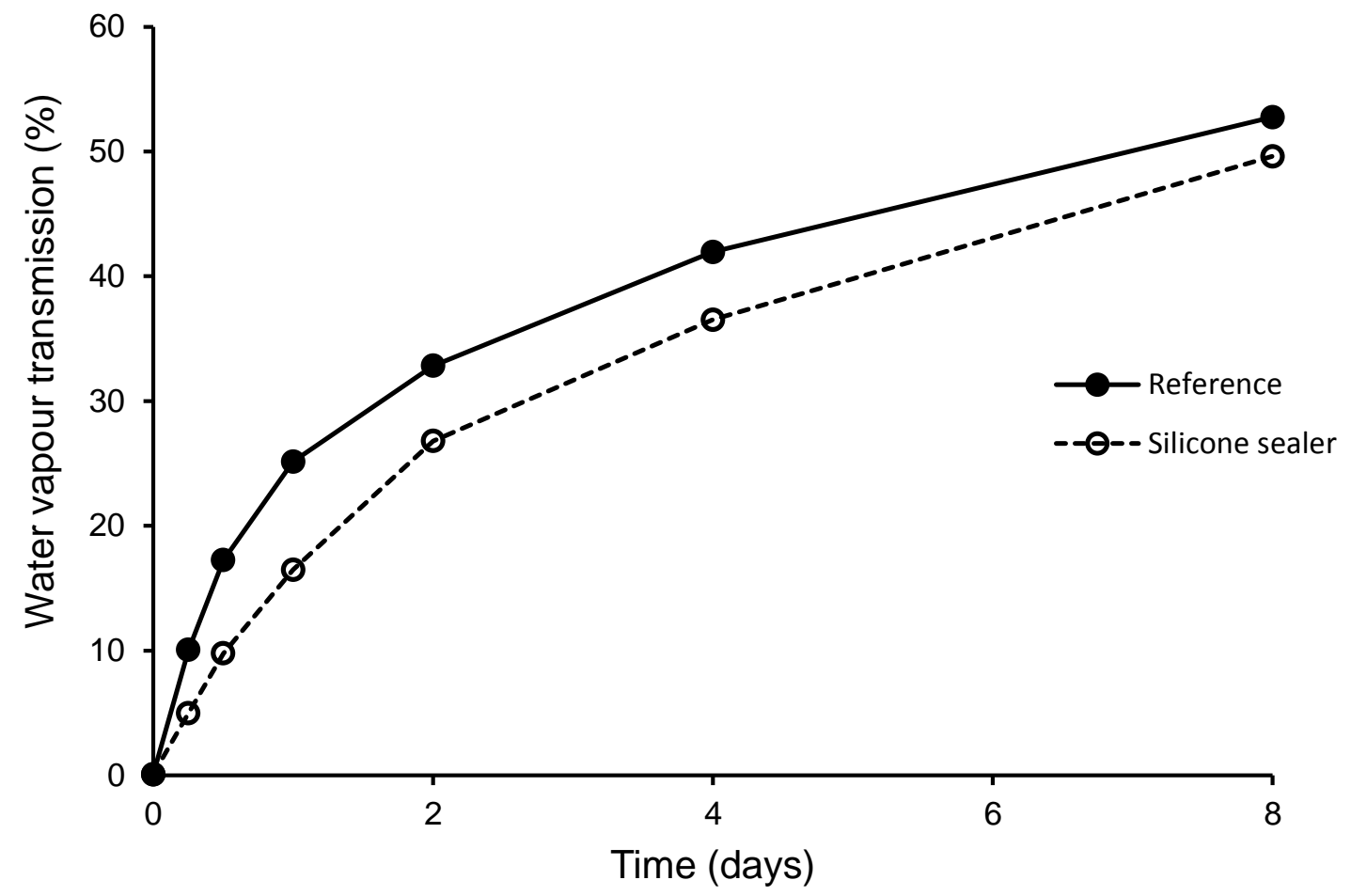

Fig. 19 Vapour transmission through a rammed earth substrate (after Kebao and Kagi [35]) 